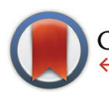

CrossMark \&click for updates

Cite this: Dalton Trans., 2016, 45 17030

Received 11th August 2016, Accepted 16th September 2016

DOI: 10.1039/c6dt03202h

www.rsc.org/dalton

\title{
The half-sandwich 18- and 16-electron arene ruthenium iminophosphonamide complexes $\uparrow$
}

\author{
Tat'yana A. Peganova, ${ }^{a}$ lana S. Sinopalnikova, ${ }^{a}$ Alexander S. Peregudov, ${ }^{a}$

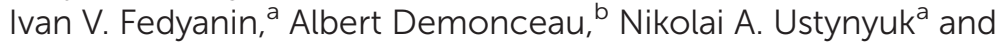 \\ Alexander M. Kalsin*a
}

\begin{abstract}
Novel half-sandwich $18 \bar{e}$ and $16 \bar{e}$ arene ruthenium iminophosphonamide complexes $\left[\left(\eta^{6}-\mathrm{C}_{6} \mathrm{Me}{ }_{6}\right) \mathrm{RuCl}\right.$ $\left.\left\{\left(\mathrm{R}^{\prime} \mathrm{N}\right)_{2} \mathrm{PR}_{2}\right\}\right](3 \mathrm{a}-\mathbf{c})$ and $\left[\left(\eta^{6}-\mathrm{C}_{6} \mathrm{Me}_{6}\right) \mathrm{Ru}\left\{\left(\mathrm{R}^{\prime} \mathrm{N}\right)_{2} \mathrm{PR}_{2}\right\}\right]^{+}\left(\mathrm{X}^{-}\right)(\mathbf{4 a}-\mathbf{c})\left(\mathbf{a}, \mathrm{R}=\mathrm{Ph}, \mathrm{R}^{\prime}=p\right.$-Tol; $\mathbf{b}, \mathrm{R}=\mathrm{Et}, \mathrm{R}^{\prime}=p$-Tol; c, $\mathrm{R}=\mathrm{Ph}, \mathrm{R}^{\prime}=\mathrm{Me} . \mathrm{X}=\mathrm{BF}_{4}, \mathrm{PF}_{6}$ or $\mathrm{BAr}_{4}$ ) were synthesized. The elongated $\mathrm{Ru}-\mathrm{Cl}$ bond in the $18 \mathrm{e} \mathrm{com}-$ plexes is shown to dissociate even in apolar solvents to form the corresponding $16 \mathrm{e}$ cations, which can be readily isolated as salts with non-coordinating anions. The coordinatively unsaturated $16 \bar{e}$ complexes are stable species due to efficient $\pi$-electron donation from the nitrogen atoms of the zwitterionic NPN-ligand. The ruthenium iminophosphonamides are moderately active in the ROMP polymerization of norbornene; the $16 \bar{e}$ complexes $4 \mathrm{a}$, b yield high molecular weight polymers $\left(M_{\mathrm{n}} \sim 300 \times 10^{3}\right)$ with a narrow distribution $M_{\mathrm{w}} / M_{\mathrm{n}} \sim 1.6$, while the $18 \mathrm{e}$ complexes $3 \mathrm{a}$, $\mathrm{b}$ give polymers of lower molecular weight $\left(M_{\mathrm{n}}<50 \times 10^{3}\right)$ with a wider polydispersity index $M_{\mathrm{w}} / M_{\mathrm{n}} \sim 2.5$.
\end{abstract}

\section{Introduction}

Among transition metal complexes with $\kappa^{2}-N, N$-heteroallylic ligands, the iminophosphonamides bearing a coordinated $\mathrm{R}_{2} \mathrm{P}\left(\mathrm{NR}^{\prime}\right)_{2}{ }^{-}$anion (NPN) are studied fragmentarily; there have been less than a hundred of molecular structures of NPN complexes established to date, that is in sharp contrast to more than a thousand of transition metal amidinate structures, according to the Cambridge Structural Database (CSD). The IV group metals, ${ }^{1-6}$ chromium, ${ }^{7-10}$ nickel $^{11-15}$ and copper ${ }^{16-22}$ iminophosphonamides are the most studied, which is due to their catalytic application in cyclopropanation, ${ }^{16,21,23}$ olefin oligomerization $^{7-9}$ and polymerization. ${ }^{2,6,12,15,24,25} \mathrm{~A}$ few platinum metal group iminophosphonamides have been reported for palladium ${ }^{24}$ and ruthenium ${ }^{26}$ before 2009 , when we started systematic studies of these complexes. We have demonstrated experimentally from the precision X-ray data by determining the deformational electron density for the palladium complex $\left[\operatorname{Pd}\left\{\left(p-{ }^{\mathrm{i}} \mathrm{PrC}_{6} \mathrm{H}_{4} \mathrm{~N}\right)_{2} \mathrm{PPh}_{2}\right\}_{2}\right]$ that the iminophosphonamide

\footnotetext{
${ }^{a}$ A.N. Nesmeyanov Institute of Organoelement Compounds, Russian Academy of Sciences, 28 Vavilov str., 119991 Moscow, Russia. E-mail: kalsin@ineos.ac.ru ${ }^{b}$ Laboratory of Macromolecular Chemistry and Organic Catalysis, Department of Chemistry, University of Liège, Sart-Tilman (B6a), 4000 Liège, Belgium

$\dagger$ Electronic supplementary information (ESI) available: Variable-temperature ${ }^{1} \mathrm{H}$ NMR of $3 \mathbf{b}$ in toluene and the $\Delta G^{\neq}$calculations for the exchange of $E t_{\mathrm{a}}$ and $E t_{\mathrm{b}}$ in 3b in $\mathrm{CD}_{2} \mathrm{Cl}_{2}$. CCDC 1475876-1475879, 1494098 and 1494099. For ESI and crystallographic data in CIF or other electronic format see DOI: 10.1039/ c6dt03202h
}

ligand is zwitterionic $\mathrm{N}^{-}-\mathrm{P}^{+}-\mathrm{N}^{-}$having single $\mathrm{P}-\mathrm{N}$ bonds and bearing full negative charges at the nitrogen atoms. ${ }^{27}$ This result shows a big difference between the electronic properties of iminophosphonamide and amidinate complexes, which previously have been considered as having a similar heteroallylic delocalized $\pi$-electronic system. The HOMO orbital of the zwitterionic NPN ligand may have either $C_{2 \mathrm{v}}$ or $C_{\mathrm{s}}$ symmetry, ${ }^{28}$ of which the latter can efficiently donate the $\pi$-electron density from the nitrogen atoms to the $\mathrm{d}_{x z}$-orbital of the metal located in the plane of the ligand, similarly to the $\beta$-diketiminate complexes (Chart $1 \mathrm{~A}$ and $\mathrm{B}$ ). In contrast, the $C_{2 \mathrm{v}}$ symmetry of the HOMO orbital in the amidinate ligand allows $\pi$-donation only by lateral coordination of the amidinate ligand resulting in a strong folding of the four-membered metallacycle (Chart 1C).

Indeed, the electron deficient ruthenium complexes can be stabilized by intramolecular $\pi$-coordination of the amidinate ligand, which leads to strong puckering of the $\mathrm{Ru}-\mathrm{N}-\mathrm{C}-\mathrm{N}$ metallacycle in the $16 \bar{e}$ complexes $\left[\left(\mathrm{Cp}^{*}\right) \mathrm{Ru}\left\{\left({ }^{t} \mathrm{BuN}\right)_{2} \mathrm{C}(\mathrm{Mes})\right\}\right]^{29}$ and $\left[\left(\mathrm{C}_{6} \mathrm{Me}_{6}\right) \mathrm{Ru}\left\{\left({ }^{\mathrm{i}} \mathrm{PrN}\right)_{2} \mathrm{CMe}\right\}\right]^{30}$ to $39.9^{\circ}$ and $31.5^{\circ}$, respectively. The lateral coordination of the amidinate ligand stabilizes these $16 \bar{e}$ complexes inefficiently since it weakens the $\mathrm{M}-\mathrm{N}$ $\sigma$-bonds; such species are very reactive and can readily coordinate $2 \overline{\mathrm{e}}$ donors ${ }^{30-32}$ or other organometallic moieties to form dinuclear $\mu^{2}$-amidinate complexes. ${ }^{33}$ At the same time, the solely reported ruthenium iminophosphonamide, the stable 16ē $\left[(p\right.$-cymene $\left.) \mathrm{Ru}\left\{\left({ }^{\mathrm{i}} \mathrm{PrN}\right)_{2} \mathrm{PPh}\left(\mathrm{NH}^{\mathrm{i}} \mathrm{Pr}\right)\right\}\right]\left(\mathrm{BPh}_{4}\right)$, did not react either with $\left[\mathrm{Et}_{3} \mathrm{NH}\right] \mathrm{Cl},\left[\mathrm{PPh}_{4}\right] \mathrm{Cl}$ or with triphenylphosphine and triphenyl phosphite to form 18ē adducts; only carbon monoxide or cyanide could coordinate, however the corres- 
(A)
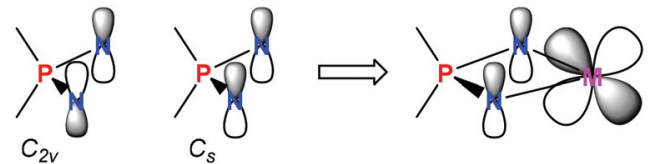

(B)

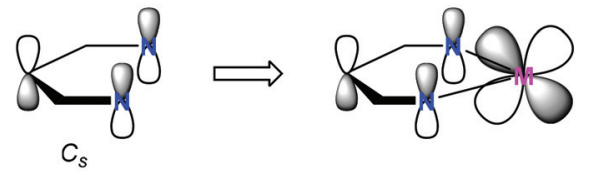

(C)

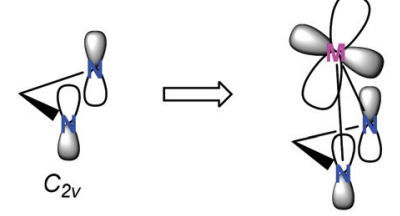

Chart 1 Schematic drawing of the HOMO orbitals of (A) iminophosphonamide, (B) $\beta$-diketiminate, and (C) amidinate ligands (on the left) and possible $\pi$-bonding with the $d$-orbital of the metal (on the right).

ponding $18 \overline{\mathrm{e}}$ complexes were not isolated. ${ }^{26}$ For this complex the authors proposed a possibility of pseudo $\pi$-allyl donation to ruthenium based on a slight puckering of the $\mathrm{Ru}-\mathrm{N}-\mathrm{P}-\mathrm{N}$ plane by $13.9^{\circ}$. Since that time the chemistry of ruthenium iminophosphonamides has not progressed, although two structures of $18 \overline{\mathrm{e}}\left[(p\right.$-cymene $) \operatorname{RuBr}\left\{(p \text {-TolN })_{2} \mathrm{PMe}(p\right.$-TolNH $\left.\left.)\right\}\right]$ and $17 \overline{\mathrm{e}}\left[\left(\mathrm{Cp}^{*}\right) \operatorname{RuCl}\left\{(p \text {-TolN })_{2} \mathrm{PMe}(p\right.\right.$-TolNH $\left.\left.)\right\}\right]$ complexes were deposited in CSD in 2004-2005 but their synthesis and properties were not published.

Recently, an interesting arene ruthenium bis(phosphinimino)methanide complex $[(p$-cymene $) \mathrm{Ru}(\mathrm{L}) \mathrm{Cl}]\left(\mathrm{L}=\mathrm{PhN}\left(\mathrm{PPh}_{2}\right)\right.$ $\left.\mathrm{CH}\left(\mathrm{PPh}_{2}\right) \mathrm{NPh}\right)$ has been shown to exist as a cationic $18 \overline{\mathrm{e}}$ complex with a tridentate $\kappa^{3}-C, N, N$ ligand $\mathrm{L}^{34}$ Although this ligand closely relates to iminophosphonamides, the stabilization of the $16 \bar{e}$ species occurs by intramolecular coordination of the methanide group but not by the unpaired electron density from the nitrogen atoms. Indeed the displacement of the methanide group by $\mathrm{Cl}^{-}$or MeCN is highly unfavorable with the $\Delta G_{298}^{\circ}$ calculated for the latter reaction to be $+19 \mathrm{kcal} \mathrm{mol}^{-1}$. This complex fails to react with $\mathrm{CO}$ under ambient conditions, which has also been attributed to the high nucleophilicity of the methanide group and the weak $\pi$-basicity of the ruthenium center. ${ }^{35}$

Here we report the synthesis of a series of new $18 \overline{\mathrm{e}}$ and $16 \overline{\mathrm{e}}$ half-sandwich arene ruthenium complexes with various iminophosphonamide ligands distinguished by the electronic properties of their $N$ - and $P$-substituents, their physico-chemical and structural data in comparison to other $\kappa^{2}-N, N$-heteroallylic arene ruthenium complexes, and preliminary catalytic data for the ring-opening metathesis polymerization (ROMP) of norbornene.

\section{Results and discussion}

\section{Synthesis and characterization of the complexes 3-4}

The synthesis of arene ruthenium NPN-complexes (3-4) from the diaminophosphonium salts $\mathbf{1 a - c}$ is summarized in Scheme 1.
The diaminophosphonium salts $\left[\mathrm{R}_{2} \mathrm{P}\left(\mathrm{NHR}^{\prime}\right)_{2}\right] \mathrm{Br}(\mathbf{1 a}-\mathbf{c})$ were prepared in high yields, according to the earlier developed procedure. ${ }^{36}$ The salts 1a-c can be monodeprotonated with strong bases like NaHMDS or $n$-BuLi to give the corresponding iminophosphonamines 2a-c, while the more acidic 1a is deprotonated easily with an equimolar amount of $\mathrm{Et}_{2} \mathrm{NH}$ to yield $2 \mathrm{a}$ quantitatively. At the same time, NaHMDS is preferred for the synthesis of $\mathbf{2 b}$ and $\mathbf{2 c}$; when $n$-BuLi is employed, the isolation of these iminophosphonamines is very laborious due to their complexation with lithium salts. The new compounds $\mathbf{1 b}$ and 2a,b were fully characterized spectroscopically and by elemental analysis, while we were not able to obtain satisfactory elemental analysis for $2 \mathrm{c}$ due to its high moisture sensitivity. In ${ }^{31} \mathrm{P}$ NMR the phosphorus signals of $\mathbf{2 a - c}$ are shifted by 27-32 ppm to less positive values compared to those of $\mathbf{1 a - c}$. In ${ }^{1} \mathrm{H}$ NMR, the $\mathrm{NH}$ hydrogen of $\mathbf{1 a}(\delta 9.26)$ is more acidic than the NH groups of $\mathbf{1 b}(\delta 8.77)$ and $\mathbf{1 c}(\delta 6.61)$ thus reflecting the electron-releasing effect of the $N$ - and $P$-substituents on the electron density at the nitrogen atoms. Expectedly, the basic $\mathrm{NH}$ resonances of the iminophosphonamines $2 \mathrm{a}(\delta 5.55)$ and 2b $(\delta 3.85)$ are shifted to less positive values. The signals from chemically inequivalent substituents at the nitrogen atoms in iminophosphonamines $\mathbf{2 a , \mathbf { b }}$ are averaged tentatively due to intermolecular $\mathrm{N}-\mathrm{H} \cdots \mathrm{N}$ proton exchange; ${ }^{37}$ perhaps such exchange is responsible for not observing the NH signal for $2 \mathrm{c}$.

Further deprotonation of $\mathbf{2 a - c}$ with 1 equiv. of NaHMDS results in the formation of sodium iminophosphonamides $\mathrm{Na}$ $\left[\mathrm{R}_{2} \mathrm{P}\left(\mathrm{NR}^{\prime}\right)_{2}\right]$, as indicated by the new signals in ${ }^{31} \mathrm{P}$ NMR at more positive values $\delta 7.0\left(\mathrm{R}=\mathrm{Ph}, \mathrm{R}^{\prime}=p\right.$-Tol $), \delta 29.0\left(\mathrm{R}=\mathrm{Et}, \mathrm{R}^{\prime}=\right.$ $p$-Tol) and $\delta 28.5\left(\mathrm{R}=\mathrm{Ph}, \mathrm{R}^{\prime}=\mathrm{Me}\right)$ with respect to the corresponding iminophosphonamines $2 \mathbf{a}-\mathbf{c} ; ;^{14,27,38}$ however they were not isolated due to extremely high moisture sensitivity. The iminophosphonamides $\mathrm{Na}\left[\mathrm{R}_{2} \mathrm{P}\left(\mathrm{NR}^{\prime}\right)_{2}\right]$ generated in situ react with the dimeric ruthenium complex $\left[\left(\eta^{6}-\mathrm{C}_{6} \mathrm{Me}_{6}\right) \mathrm{RuCl}_{2}\right]_{2}$ to give the corresponding $18 \bar{e}$ arene ruthenium(II) complexes $3 \mathbf{a}-\mathbf{c}$ with the chelating bidentate NPN-ligand in moderate-to-high isolated yields (62-86\%). The chloride ligand in 3a-c was easily replaced with the non-coordinating anions $\left(\mathrm{PF}_{6}{ }^{-}, \mathrm{BF}_{4}{ }^{-}, \mathrm{BAr}_{4}{ }_{4}\right)$ by treating them with the corresponding silver or sodium salts in dichloromethane to afford the new $16 \overline{\mathrm{e}}$ cationic complexes $\left[\left(\eta^{6}-\mathrm{C}_{6} \mathrm{Me}_{6}\right) \mathrm{Ru}\left\{(p-\mathrm{TolN})_{2} \mathrm{PPh}_{2}\right\}\right]\left(\mathrm{PF}_{6}\right) \quad(\mathbf{4 a}), \quad\left[\left(\eta^{6}-\mathrm{C}_{6} \mathrm{Me}_{6}\right) \mathrm{Ru}\right.$ $\left.\left\{(p-\mathrm{TolN})_{2} \mathrm{PEt}_{2}\right\}\right]\left(\mathrm{BF}_{4}\right) \quad(\mathbf{4 b})$ and $\left[\left(\eta^{6}-\mathrm{C}_{6} \mathrm{Me}_{6}\right) \mathrm{Ru}\left\{(\mathrm{MeN})_{2} \mathrm{PPh}_{2}\right\}\right]$ $\left(\mathrm{BAr}_{4}^{\mathrm{F}}\right)(\mathbf{4 c})$ in nearly quantitative yields as deep-violet solids. All the complexes obtained were fully characterized by NMR spectroscopy and elemental analysis and their molecular structures were confirmed by single crystal X-ray diffraction studies. The selected structural parameters of $\mathbf{3 a - c}$ and $\mathbf{4 a - c}$ are given in Table 1 and their projections are shown in Fig. 1-6.

The $18 \bar{e}$ complexes $3 \mathbf{a}-\mathbf{c}$ exhibit a three-legged piano stool geometry with a pseudo-octahedral configuration of the ligands around the ruthenium atom. The $\mathrm{Ru}-\mathrm{C}_{6} \mathrm{Me}_{6}$ (centroid) distance is in the range of 1.675(3)-1.662(4) $\AA$, which is typical of neutral half-sandwich arene ruthenium complexes. Similarly to the $\beta$-diketiminate arene ruthenium complex, ${ }^{39}$ in both $\mathbf{3 a} \mathbf{a}, \mathbf{b}$ the $\mathrm{C}-\mathrm{C}$ bond lengths in the $\eta^{6}$-coordinated arene noticeably alternate: the bonds $\mathrm{C}(2)-\mathrm{C}(3), \mathrm{C}(4)-\mathrm{C}(5)$, and $\mathrm{C}(1)-\mathrm{C}(6)$, which are 


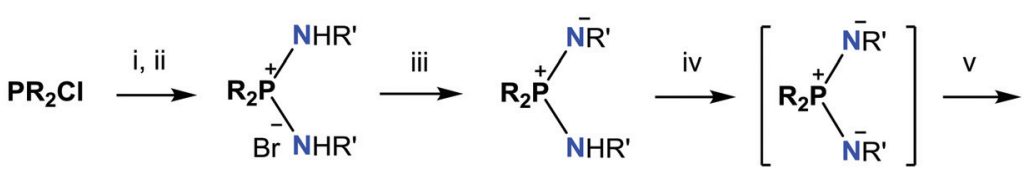

1
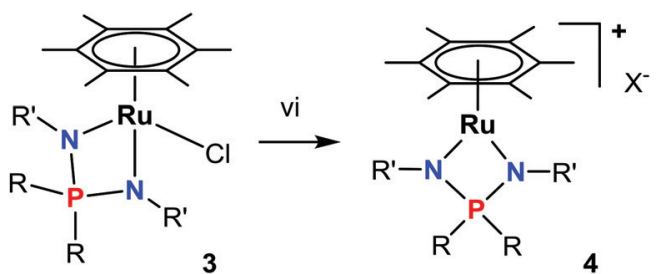

a, $\mathrm{R}=\mathrm{Ph}, \mathrm{R}^{\prime}=p-\mathrm{Tol}$

b, $\mathrm{R}=\mathrm{Et}, \mathrm{R}^{\prime}=p-\mathrm{Tol}$

i) $\mathrm{Br}_{2}, \mathrm{CH}_{2} \mathrm{Cl}_{2}, 0^{\circ} \mathrm{C}$; ii) $4 \mathrm{R}^{\prime} \mathrm{NH}_{2}$; iii) 1 eq. $\mathrm{Et}_{2} \mathrm{NH}$ or NaHMDS;

c, $R=P h, R^{\prime}=M e$

iv) 1 eq. NaHMDS; v) $\left[\left(\mathrm{C}_{6} \mathrm{Me}_{6}\right) \mathrm{RuCl}_{2}\right]_{2}, \mathrm{C}_{6} \mathrm{H}_{6}$; vi) $\mathrm{AgBF}_{4}, \mathrm{CH}_{2} \mathrm{Cl}_{2}$.

Scheme 1 Synthesis of complexes 3-4.

Table 1 Selected geometrical parameters of complexes $3 a-c$ and $4 a-c$ : the distances $(\AA \AA)$, angles and dihedrals $\left(^{\circ}\right)$

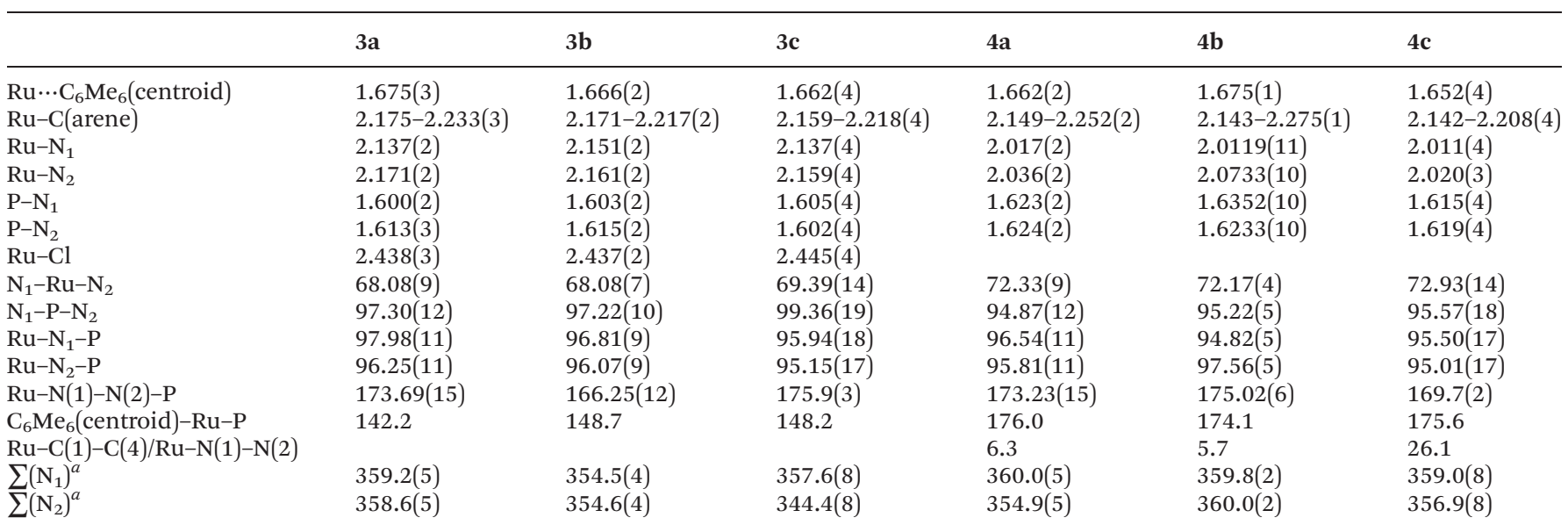

${ }^{a}$ The sum of bond angles at the corresponding nitrogen atom.

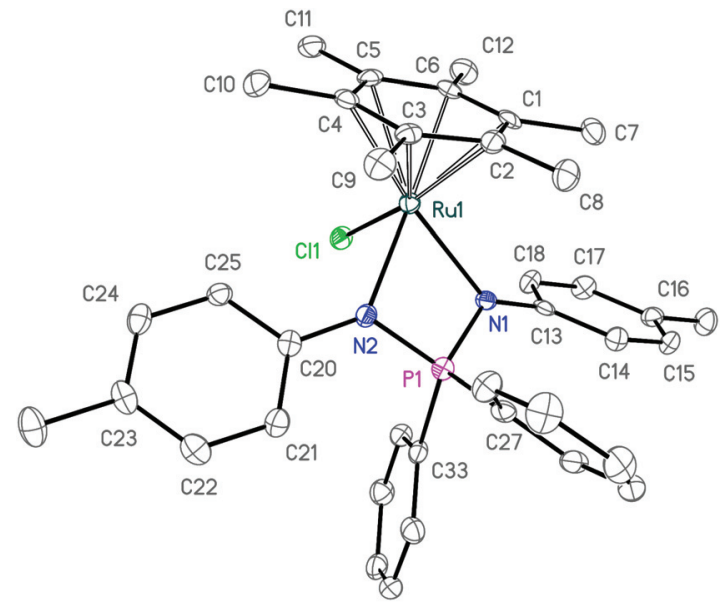

Fig. 1 ORTEP diagram of complex 3a. Ellipsoids are shown at 50\% probability, hydrogen atoms are omitted for clarity.

trans to the $\mathrm{N}(1), \mathrm{N}(2)$ and $\mathrm{Cl}(1)$, are shorter (1.412-1.421 $\AA$ for 3a and 1.417-1.423 $\AA$ for $3 \mathbf{b})$ than the bonds $\mathrm{C}(1)-\mathrm{C}(2), \mathrm{C}(3)-$ $\mathrm{C}(4)$, and $\mathrm{C}(5)-\mathrm{C}(6)$ (1.436-1.442 $\AA$ for 3a and 1.442-1.447 $\AA$ for $3 \mathbf{b})$. In contrast to this, in $3 \mathbf{c}$ the coordinated arene gives a nearly eclipsed conformation with the chloride and the NPN-

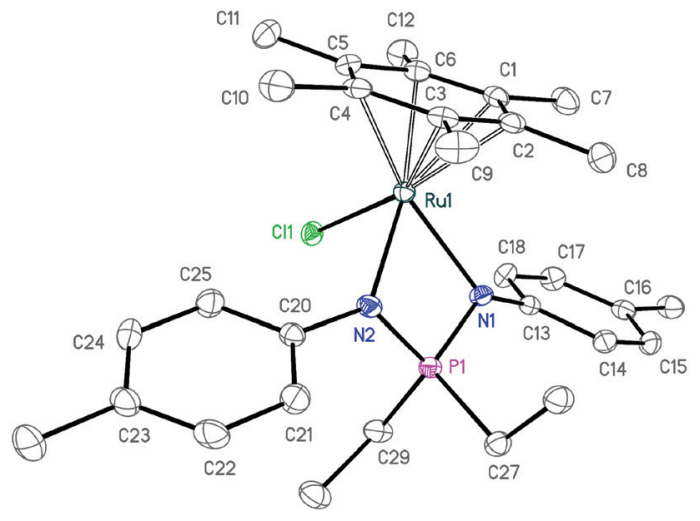

Fig. 2 ORTEP diagram of complex 3b. Ellipsoids are shown at 50\% probability, hydrogen atoms are omitted for clarity.

ligands; only $\mathrm{N}(1)$ significantly deviates from that (the torsion angle $\mathrm{N}(1)-\mathrm{Ru}-\mathrm{C}_{6} \mathrm{Me}_{6}\left(\right.$ centroid) $-\mathrm{C}(1)$ is $\left.18.5^{\circ}\right)$, which results in shortening of the $\mathrm{C}(4)-\mathrm{C}(5)$ bond trans to $\mathrm{N}(1)(1.417 \AA)$, while the other $\mathrm{C}-\mathrm{C}$ bonds are slightly longer $(1.428-1.441 \AA)$.

In iminophosphonamide complexes $3 \mathbf{a}-\mathbf{c}$ the $\mathrm{Ru}-\mathrm{N}$ bonds (2.137-2.171 $\AA$ ) and the $\mathrm{Ru}-\mathrm{Cl}$ bonds (2.437-2.445 $\mathrm{A}$ ) are considerably longer than those in analogous $18 \overline{\mathrm{e}}$ arene ruthenium 


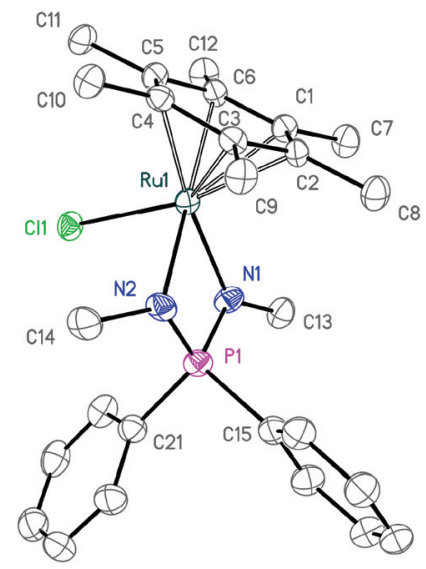

Fig. 3 ORTEP diagram of complex 3c. Ellipsoids are shown at 50\% probability, hydrogen atoms are omitted for clarity.

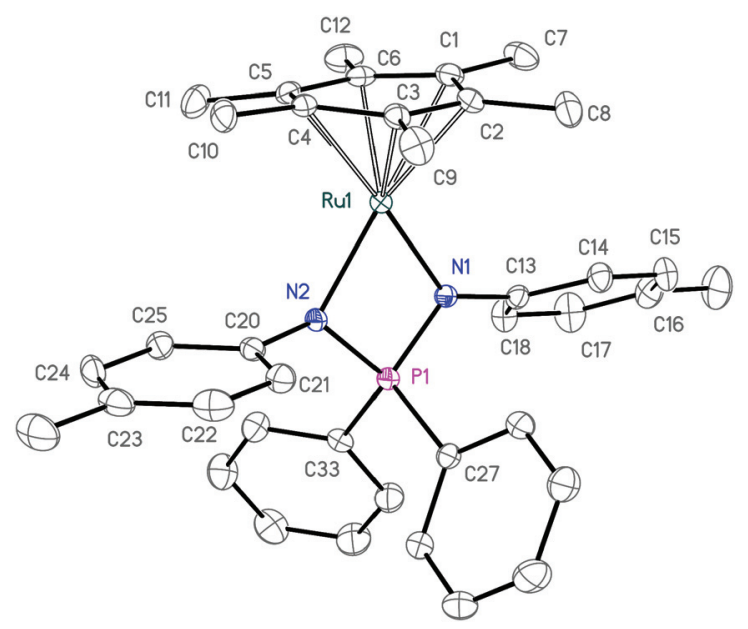

Fig. 4 ORTEP diagram of cation 4 a. Ellipsoids are shown at $50 \%$ probability, hydrogen atoms and the anion are omitted for clarity.

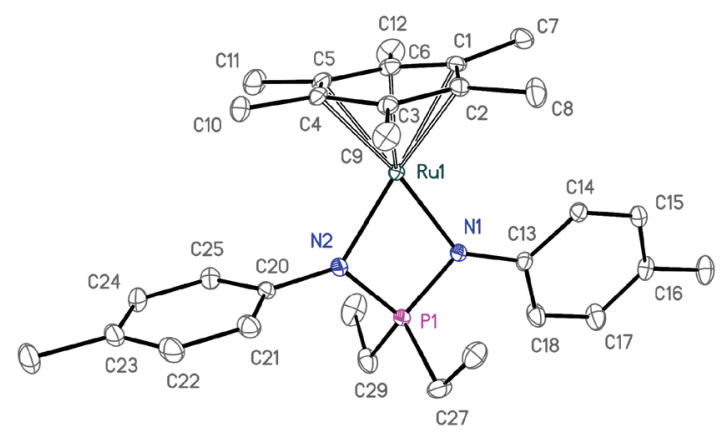

Fig. 5 ORTEP diagram of cation 4 b. Ellipsoids are shown at $50 \%$ probability, hydrogens atoms and the anion are omitted for clarity.

amidinate $(2.078-2.139 \AA \text { and } 2.400-2.434 \AA \text {, respectively })^{40-44}$ or triazenide $(2.104-2.133 \AA \text { and } 2.386-2.397 \AA)^{45}$ complexes, perhaps due to the high negative charge located at the nitrogen atoms of the zwitterionic NPN-ligand. Indeed, the $\mathrm{Ru}-\mathrm{Cl}$

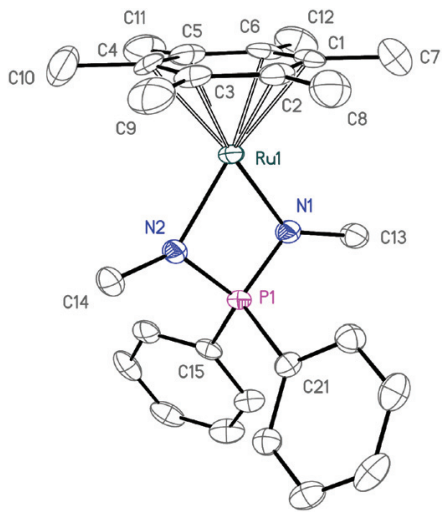

Fig. 6 ORTEP diagram of the cation 4c. Ellipsoids are shown at 50\% probability, hydrogen atoms and the anion are omitted for clarity.

bond is elongated in arene ruthenium complexes with highly efficient $\sigma, \pi$-donating $\beta$-diketiminate $(2.461-2.521 \AA)^{39,46,47}$ or dianionic bis(imidazolin-2-iminate) $(2.4853(4) \AA)$ ligands ${ }^{48}$ up to full dissociation in the latter example.

The chlorine atom has intramolecular close $\mathrm{CH} \cdots \mathrm{Cl}$ contacts with one ortho-hydrogen (H18A) of the $N$-tolyl substituents. The $\mathrm{H} 18 \mathrm{~A} \cdots \mathrm{Cl}$ distances in $\mathbf{3 a}(2.762 \AA)$ and $\mathbf{3 b}(2.813 \AA)$ fall below the sum of the van der Waals radii of $2.95 \AA$ (ref. 49 and 50) and the corresponding angles $\mathrm{Cl} \cdots \mathrm{H}-\mathrm{C}$ of $140.4^{\circ}$ (3a) and $140.8^{\circ}(3 \mathbf{b})$ are typical of such a type of non-directed interaction. The chlorine atom is almost coplanar to the plane of the tolyl ring involved in the $\mathrm{H} \cdots \mathrm{Cl}$ contact and the corresponding torsion angle $\mathrm{Cl}-\mathrm{H}(18 \mathrm{~A})-\mathrm{C}(18)-\mathrm{C}(13)$ is $7.6^{\circ}$ and $8.4^{\circ}$ for $\mathbf{3 a}$ and $\mathbf{3} \mathbf{b}$, respectively. A few other intra- and intermolecular close contacts $\mathrm{H} \cdots \mathrm{Cl}$ are observed in $\mathbf{3 a} \mathbf{a}, \mathbf{b}$ with the hydrogens of the $\mathrm{C}_{6} \mathrm{Me}_{6}$ ligand (the $\mathrm{Cl} \cdots \mathrm{H} 11 \mathrm{C}, \mathrm{Cl} \cdots \mathrm{H} 11 \mathrm{~B}$ distances are $2.772,2.749 \AA$ in $\mathbf{3 a}$ and the $\mathrm{Cl} \cdots \mathrm{H} 11 \mathrm{C}, \mathrm{Cl} \cdots \mathrm{H} 8 \mathrm{~A}$ are $2.899,2.871 \AA$ in $\mathbf{3 b}$ ) and of the $P$-substituent (the $\mathrm{Cl} \cdots \mathrm{H} 34 \mathrm{~A}$ is $2.868 \AA$ in $3 \mathbf{a}$ and the $\mathrm{Cl} \cdots \mathrm{H} 29 \mathrm{~A}$ is $2.812 \AA$ in $3 \mathbf{b})$. Similar intraand intermolecular close contacts can be seen in $3 \mathbf{c}$ between the chlorine atom and the hydrogen atoms of the methyl group at $\mathrm{N}(2)(\mathrm{Cl} \cdots \mathrm{H} 14 \mathrm{~B}$ is $2.872 \AA)$ and $\mathrm{C}_{6} \mathrm{Me}_{6}(\mathrm{Cl} \cdots \mathrm{H} 10 \mathrm{C}$ is $2.840 \AA$ Å), respectively.

The chelate angle $\mathrm{N}(1)-\mathrm{Ru}-\mathrm{N}(2)$ in $3 \mathrm{a}-\mathrm{c}\left(68.1-69.4^{\circ}\right)$ is significantly larger than that in the analogous $18 \overline{\mathrm{e}}$ ruthenium amidinate complexes $\left(61-62^{\circ}\right),{ }^{40-43,51}$ since the $\mathrm{P}-\mathrm{N}$ bonds are longer than the corresponding $\mathrm{C}-\mathrm{N}$ bonds in the amidinates. It is worth noting that the torsion angle $\mathrm{Ru}-\mathrm{N}(1)-\mathrm{N}(2)-\mathrm{P}$ is close to $180^{\circ}$ showing small puckering of the $\mathrm{Ru}-\mathrm{N}(1)-\mathrm{P}-\mathrm{N}(2)$ metallacycle from the planarity $\left(6.3^{\circ}\right.$ for $3 \mathbf{a}, 13.7^{\circ}$ for $3 \mathbf{b}$ and $4.1^{\circ}$ for $3 \mathrm{c}$ ). The pyramidalization of the nitrogen atoms is rather small in $\mathbf{3 a}, \mathbf{b}$, while it is strong for one of the nitrogens in $3 \mathbf{c}$, for which the sum of the angles at the $\mathrm{N}(2)$ atom $\sum(\mathrm{N})$ is $344.4^{\circ}$. Recently, a much wider range of puckering angles (up to $23.4^{\circ}$ ) and relatively strong pyramidalization of one of the nitrogen atoms $\left(348-351^{\circ}\right)$ were observed in the square-planar palladium iminophosphonamide complexes, presumably as a result of steric repulsion between the $N$-cumyl substituents of the NPN- and co-ligands. ${ }^{27}$ However this seems to be not the 
case of $3 \mathbf{c}$ bearing sterically small $N$-methyl groups; more probably the pyramidalization of $\mathrm{N}(2)$ is due to the high unpaired electron density located fully at the nitrogen atom and being not able to delocalize on any other electron system like aromatic $N$-tolyl groups in $\mathbf{3 a}, \mathbf{b}$.

The 16ê cationic complexes 4a-c expectedly exhibit a twolegged piano-stool geometry with the chelating NPN-ligand positioned nearly perpendicular to the $\mathrm{C}_{6} \mathrm{Me}_{6}$ ring; the $\mathrm{C}_{6} \mathrm{Me}_{6}$ (centroid) $-\mathrm{Ru}-\mathrm{P}$ angle is $174-176^{\circ}$. The $\mathrm{Ru}-\mathrm{C}_{6} \mathrm{Me}_{6}$ (centroid) distance is $1.652-1.675 \AA$ and is similar to that in $3 \mathbf{a}-\mathbf{c}$. The $\mathrm{Ru}-\mathrm{N}$ bond lengths in $\mathbf{4 a - c}(2.011-2.073 \AA)$ are close to those in $\quad\left[(p\right.$-cymene $\left.) \mathrm{Ru}\left\{\left({ }^{\mathrm{i}} \mathrm{PrN}\right)_{2} \mathrm{PPh}\left(\mathrm{NH}^{\mathrm{i}} \mathrm{Pr}\right)\right\}\right]\left(\mathrm{BPh}_{4}\right) \quad$ (5) (2.011, $2.017 \AA)^{26}$ and are significantly shorter than in $3 \mathbf{a}-\mathbf{c}$ due to stronger binding with the positively charged ruthenium atom. Slightly shorter Ru-N distances were reported for $16 \bar{e}$ cationic $\beta$-diketiminates $(1.994-1.997 \quad \AA)^{39}$ and bis(imidazolin-2-iminates) $(1.977-2.003 \AA),{ }^{48}$ while in the analogous ruthenium amidinate complexes these bonds are longer (2.058-2.065 ̊̊),,$^{30,32}$ showing the intermediate donating ability of the NPN-ligand. The $\mathrm{C}_{6} \mathrm{Me}_{6}$ ring is not planar but is significantly distorted towards the boat conformation making four $\mathrm{Ru}-\mathrm{C}($ arene) bonds shorter $(2.149-2.178(2) \AA$ in $\mathbf{4 a}$ and 2.143-2.199(1) $\AA$ in $4 \mathbf{b})$ and two bonds, namely $\mathrm{Ru}-\mathrm{C}(1)$ and $\mathrm{Ru}-\mathrm{C}(4)$ (2.238(2), 2.252(2) ̊ for 4a and 2.228(1), 2.275(1) ̊̊ for 4b), longer. Unlike in the $18 \bar{e}$ complexes $3 \mathbf{a}, \mathbf{b}$, the $\mathrm{C}-\mathrm{C}$ bonds in $\mathrm{C}_{6} \mathrm{Me}_{6}$ in $\mathbf{4 a}, \mathbf{b}$ do not alternate, instead the bonds $\mathrm{C}(2)-\mathrm{C}(3)$ and $\mathrm{C}(5)-\mathrm{C}(6)(1.440-1.444 \AA)$ are slightly longer than the other four C-C bonds (1.418-1.428 $\AA$ ) as a result of the stronger bonding of these carbons with the ruthenium atom. Importantly, in $\mathbf{4 a}, \mathbf{b}$ the longer $\mathrm{Ru}-\mathrm{C}(1)$ and $\mathrm{Ru}-\mathrm{C}(4)$ bonds are always trans to the $\mathrm{Ru}-\mathrm{N}$ bonds (the dihedral angle between the planes $\mathrm{Ru}-\mathrm{C}(1)-\mathrm{C}(4)$ and $\mathrm{Ru}-\mathrm{N}(1)-\mathrm{N}(2)$ is $\left.5.7-6.3^{\circ}\right)$ with the longest $\mathrm{Ru}-\mathrm{C}(4)$ bond trans to the shortest $\mathrm{Ru}-\mathrm{N}(2)$ bond. A similar distortion of the coordinated arene planarity and the $\mathrm{Ru}-\mathrm{C}$ (arene) bond distribution was earlier observed for $5^{26}$ and dicationic arene ruthenium complexes with the bis(imidazolin-2-imine) ligand. ${ }^{48}$ It should be noted that in $4 \mathbf{c}$ the arene and the NPN-ligand are in a staggered conformation (the dihedral angle between the planes $\mathrm{Ru}-\mathrm{C}(2)-\mathrm{C}(5)$ and $\mathrm{Ru}-\mathrm{N}(1)-$ $\mathrm{N}(2)$ is $86.1^{\circ}$ ), which leads to slight shortening of the $\mathrm{Ru}-\mathrm{C}(2)$ and $\mathrm{Ru}-\mathrm{C}(5)$ (2.142(4), 2.163(4) $\mathrm{\AA}$ ) compared to the other four $\mathrm{Ru}-\mathrm{C}$ (arene) bonds (2.177-2.208 $\mathrm{A})$ resulting in a flipped boat conformation of the arene.

The chelate angle $\mathrm{N}(1)-\mathrm{Ru}-\mathrm{N}(2)$ in $\mathbf{4 a}-\mathbf{c}\left(72.1-72.9^{\circ}\right)$ is almost equal to that in $\mathbf{5}\left(71.8^{\circ}\right)^{26}$ and larger by $c a .4^{\circ}$ than in 3a-c. The pyramidalization of the nitrogen atoms $\left(\sum(\mathrm{N})\right.$ is $\left.355-360^{\circ}\right)$ and the puckering of the plane $\operatorname{Ru}(1) \mathrm{N}(1) \mathrm{P}(1) \mathrm{N}(2)$ $\left(5.0-10.3^{\circ}\right)$ are small. This is in sharp contrast to the strong puckering $\left(31.4^{\circ}\right)$ of the chelate metallacycle $\mathrm{M}-\mathrm{N}-\mathrm{C}-\mathrm{N}$ in the analogous amidinate $16 \overline{\mathrm{e}}$ arene ruthenium complex $\left[\left(\eta^{6}-\mathrm{C}_{6} \mathrm{Me}_{6}\right) \mathrm{Ru}\left\{\left(\mathrm{N}^{\mathrm{i}} \mathrm{Pr}\right)_{2} \mathrm{CMe}\right\}\right]\left(\mathrm{PF}_{6}\right)$, required for additional stabilization of the coordinatively unsaturated species by a $\pi$-heteroallyl system. ${ }^{30}$

The structural peculiarities of the coordinated arene, the flattened RuNPN metallacycle and the short $\mathrm{Ru}-\mathrm{N}$ bonds in $\mathbf{4 a - c}$ are indicative of the strong $\sigma, \pi$-bonding of the iminopho- sphonamide ligand ${ }^{26}$ via nitrogen atoms, similarly to $\beta$-diketiminates and bis(imidazolin-2-iminates), and in contrast to allylic $\pi$-stabilization in metal amidinates. The elongated $\mathrm{Ru}-\mathrm{Cl}$ bonds in $\mathbf{3 a}-\mathbf{c}$ and the pyramidalization of the nitrogen atom in the most electron-rich $3 \mathbf{c}$ are also in agreement with the zwitterionic structure of the NPN ligand bearing enhanced negative charges at the nitrogen atoms.

In the ${ }^{31} \mathrm{P}$ NMR spectra of $\mathbf{3 a} \mathbf{a}, \mathbf{b}$ the phosphorus resonance ( $\delta 43.9$ for $3 \mathbf{a}$ and $\delta 72.4$ for $\mathbf{3 b}$ ) is shifted by $c a$. $47-49 \mathrm{ppm}$ to more positive values compared to the precursors $2 \mathbf{a}$ and $2 \mathbf{b}$. Interestingly, in the ${ }^{1} \mathrm{H}$ NMR spectra of $\mathbf{3 a}$ and $\mathbf{3} \mathbf{b}$ in $\mathrm{CDCl}_{3}$ the two chemically inequivalent substituents at the phosphorus atom give only one set of signals for phenyl and ethyl groups, respectively. However, in the ${ }^{1} \mathrm{H}$ NMR spectra recorded in apolar $\mathrm{C}_{6} \mathrm{D}_{6}$, the $P$-substituents of $\mathbf{3 a}$ and $\mathbf{3} \mathbf{b}$ give rise to two sets of the corresponding resonances. Similarly, in the ${ }^{13} \mathrm{C}$ NMR spectra of $\mathbf{3 a}$ and $\mathbf{3 b}$ in $\mathrm{CDCl}_{3}$ the resonances for only one type of phenyl and ethyl groups are observed. It is noteworthy that in ${ }^{13} \mathrm{C}$ NMR the characteristic doublets for ipso-carbons of phenyls are not found, perhaps due to their strong broadening. Apparently, in polar solvents fast exchange between the two $P$-substituents takes place. Indeed, heating a solution of $3 \mathbf{a}$ and $\mathbf{3 b}$ in apolar toluene- $d_{8}(T=273-353 \mathrm{~K})$ leads to broadening of the inequivalent phenyl and ethyl resonances, respectively for $\mathbf{3 a}$ and $\mathbf{3} \mathbf{b}$, in ${ }^{1} \mathrm{H}$ NMR, though their coalescence is not achieved (see the ESI $\dagger$ ). In a more polar $\mathrm{CD}_{2} \mathrm{Cl}_{2}$ solution of $3 \mathbf{b}$ at $298 \mathrm{~K}$ the signals for only one ethyl substituent are observed, while decreasing the temperature to $193 \mathrm{~K}$ gives two separate resonances of methyl groups (Fig. 7). At the coalescence temperature of $T_{\mathrm{c}}=238 \mathrm{~K}$ in dichloromethane, the estimated exchange rate constant is $1370 \mathrm{~s}^{-1}$ and the free energy of activation $\Delta G^{\neq}$calculated from the Eyring equation is about $10.4 \mathrm{kcal} \mathrm{mol}^{-1}$. $^{52}$

The exchange between the $P$-substituents $\mathrm{R}_{\mathrm{a}}$ and $\mathrm{R}_{\mathrm{b}}$ seems to proceed via a $C_{2 \mathrm{v}}$-symmetric intermediate or a transition state with two equivalent $\mathrm{R}$ groups, tentatively the cationic complex $\left[\left(\eta^{6}-\mathrm{C}_{6} \mathrm{Me}_{6}\right) \mathrm{Ru}\left\{\mathrm{R}_{2} \mathrm{P}(\mathrm{N}-p-\mathrm{Tol})_{2}\right\}\right]^{+} \mathrm{Cl}^{-}$(vide infra), formed from $\mathbf{3 a}, \mathbf{b}$ by dissociation of the chloride anion (Scheme 2).

Although the dissociation of the chloride anion in $18 \overline{\mathrm{e}}$ complexes 3a,b is facile in $\mathrm{CDCl}_{3}$ or $\mathrm{CD}_{2} \mathrm{Cl}_{2}$, the equilibrium concentration of the dissociated $16 \bar{e}$ form is negligible, as far as their signals in ${ }^{31} \mathrm{P} \mathrm{NMR}$ in $\mathrm{CDCl}_{3}(\delta 43.9$ for $\mathbf{3 a}, \delta 72.4$ for $\mathbf{3 b}$ ) and $\mathrm{C}_{6} \mathrm{D}_{6}(\delta 43.3$ for $3 \mathbf{a}, \delta 71.1$ for $3 \mathbf{b}$ ) remain virtually unchanged. The phosphorus resonance of the 16ē cationic complexes $4 \mathbf{a}(\delta$ $71.9)$ and $\mathbf{4 b}(\delta 102.3)$ is strongly shifted by $\sim 30 \mathrm{ppm}$ to more positive values compared to the neutral complexes $3 \mathbf{a}, \mathbf{b}$. In the ${ }^{1} \mathrm{H}$ and ${ }^{13} \mathrm{C}$ NMR spectra of $\mathbf{4 a}, \mathbf{b}$ in $\mathrm{CD}_{2} \mathrm{Cl}_{2}$ the $P$-substituents are chemically equivalent, independent of the temperature (193-298 K) as it is expected for $C_{2 \mathrm{v}}$-symmetric complexes.

In apolar $\mathrm{C}_{6} \mathrm{D}_{6}$ complex $3 \mathbf{c}$ also gives rise to two inequivalent phenyl groups in the ${ }^{1} \mathrm{H}$ and ${ }^{13} \mathrm{C}$ NMR spectra, which is consistent with the non-dissociated $18 \bar{e}$ chloride complex, though the signals are broadened. Whereas in more polar $\mathrm{CDCl}_{3}$ complex 3c has violet color and its ${ }^{31} \mathrm{P}$ resonance $\left(\delta\right.$ 76.9) is strongly shifted to more positive values than in $\mathrm{C}_{6} \mathrm{D}_{6}$ $(\delta 59.8)$ and becomes close to the signal of the cationic 

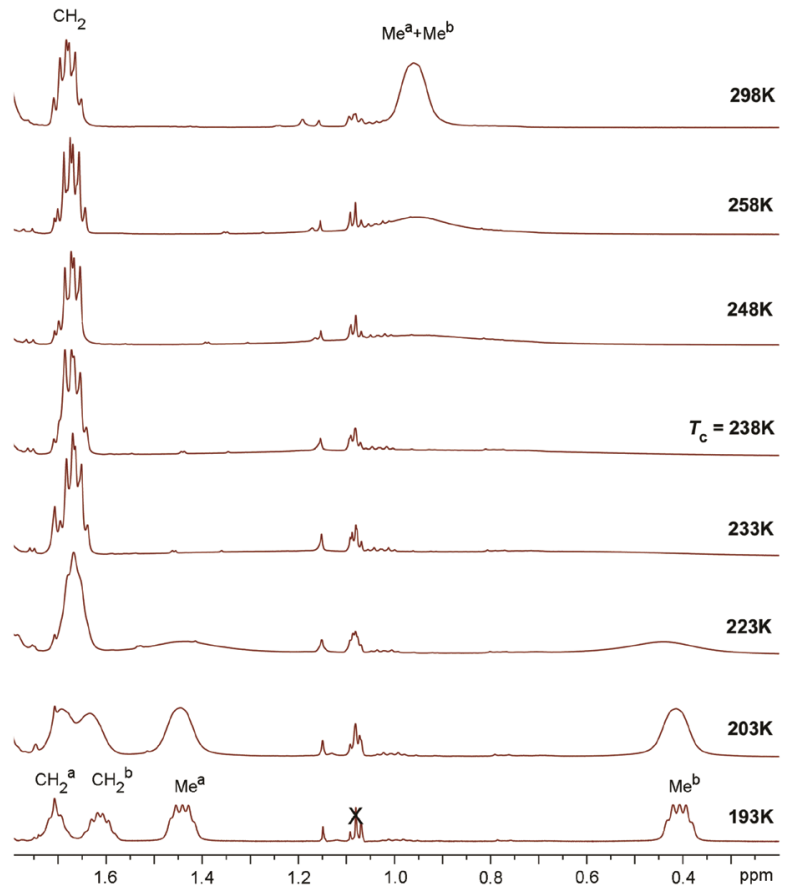

Fig. 7 VT NMR spectra of complex 3b recorded in $\mathrm{CD}_{2} \mathrm{Cl}_{2}$ at $T=$ 193-298 K ( $x$ - stands for grease).

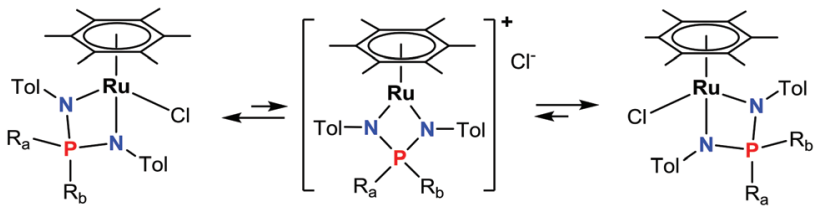

Scheme 2 The exchange between $R_{a}$ and $R_{b}$ substituents via putative dissociation-association of the chloride anion. ${ }^{53}$

complex 4c $\left(\delta\right.$ 80.8). The ${ }^{1} \mathrm{H}$ NMR spectra of $3 \mathbf{c}$ and $4 \mathbf{c}$ in $\mathrm{CDCl}_{3}$ are nearly identical and in line with the cationic $C_{2 \mathrm{v}}$-symmetric complex. Hence, in sharp contrast to $\mathbf{3 a}, \mathbf{b}$, in $\mathrm{CDCl}_{3}$ solution $3 \mathbf{c}$ undergoes facile dissociation to give the cationic complex $\left[\left(\eta^{6}-\mathrm{C}_{6} \mathrm{Me}_{6}\right) \mathrm{Ru}\left\{\mathrm{Ph}_{2} \mathrm{P}(\mathrm{NMe})_{2}\right\}\right]^{+} \mathrm{Cl}^{-}$, which is prevalent in the equilibrium mixture. Apparently strongly electron-releasing $N$-methyl substituents enhance the $\pi$-donating ability of the NPN-ligand compared to that of the complexes 3a,b bearing weaker $N$-tolyl donors.

The arene ruthenium complexes having monoanionic $\beta$-diketiminate ${ }^{39}$ and dianionic bis(imidazolin-2-iminate) $)^{48}$ ligands have also been reported earlier to undergo facile chloride dissociation, whereas in the amidinate ruthenium complexes the counter-ion dissociation has been observed only for the weakly coordinating triflate ligand but not the chloride. ${ }^{51}$ Hence the capability of the iminophosphonamide ligand to donate electrons and to stabilize the electron-deficient states is much higher than that of the amidinate ligand and comparable to the $\beta$-diketiminate and zwitterionic bis(imidazolin2-iminate) ligands.
In the UV-vis spectra the complexes 4a-c have a broad medium intensity band at $\lambda_{\max } 540-550 \mathrm{~nm}$ shifted to lower energies compared to the corresponding complexes $\mathbf{3 a , b}$ (in $\mathrm{CH}_{2} \mathrm{Cl}_{2}$ ) and 3c (in $\mathrm{C}_{6} \mathrm{H}_{6}$ ) having a band at $\lambda_{\max } 410-450 \mathrm{~nm}$. Similar bands at $\lambda_{\max } 520-530 \mathrm{~nm}$ have also been observed for $16 \bar{e}$ pentamethylcyclopentadienyl amidinate, ${ }^{29} \beta$-diketiminate ${ }^{47}$ and bis(imidazolin-2-iminate) ${ }^{48}$ ruthenium complexes, which has been attributed to $\mathrm{d}-\mathrm{d}$ centered transitions. ${ }^{47}$

The 16ē complexes $\mathbf{4 a - c}$ are remarkably stable in solution to air and moisture in sharp contrast to the $18 \overline{\mathrm{e}}$ complexes $3 \mathrm{a}-\mathbf{c}$, which hydrolyze to produce the corresponding phosphinoxides $\mathrm{R}_{2} \mathrm{P}(\mathrm{O})\left(\mathrm{NHR}^{\prime}\right)$. Apparently the nitrogen atoms in 3a-c are highly basic due to their free electron pairs and thus are prone to the attack by water molecules, whereas in $\mathbf{4 a - c}$ these electron pairs participate in $\pi$-bonding to the ruthenium atom and are much less basic. Indeed, the susceptibility to hydrolysis is higher for the complex bearing more electron-releasing $\mathrm{N}$-substituents; thus $3 \mathbf{c}$ decomposes within minutes in wet $\mathrm{CD}_{2} \mathrm{Cl}_{2}$ while $\mathbf{3 a}$,b are stable for hours. Under similar conditions $\mathbf{4 a - c}$ do not hydrolyze and do not form the $18 \overline{\mathrm{e}}$ aqua NPN-complexes; their NMR spectra in dried and wet solvents are the same and remain unchanged for days. However, when 10 equivalents of MeCN were added to a solution of $\mathbf{4 a}$ in $\mathrm{CD}_{2} \mathrm{Cl}_{2}$ the colour immediately changed from violet to red and the phosphorus resonance shifted from $\delta 72.2$ to $\delta 63.8$ indicating the formation of the new complex, presumably the cationic adduct $\left[\left(\eta^{6}-\mathrm{C}_{6} \mathrm{Me}_{6}\right) \mathrm{Ru}(\mathrm{MeCN})\left\{\mathrm{Ph}_{2} \mathrm{P}(\mathrm{N}-p-\mathrm{Tol})_{2}\right\}\right]\left(\mathrm{PF}_{6}\right)$. The attempt to isolate it by removing the excess of acetonitrile in vacuo returned the starting complex $4 \mathbf{a}$ (violet solution in $\mathrm{CD}_{2} \mathrm{Cl}_{2}$ with the phosphorus resonance at $\delta 71.0$, no acetonitrile signal in ${ }^{1} \mathrm{H}$ NMR). Bubbling carbon monoxide into a solution of $\mathbf{4 a}$ in $\mathrm{CH}_{2} \mathrm{Cl}_{2}$ leads to the formation of a yellow $\mathrm{CO}$ adduct $\left(\nu_{\mathrm{CO}}=\right.$ $1984 \mathrm{~cm}^{-1}$ ), however the CO ligand is labile and easily decoordinates upon removing the solvent under reduced pressure to give back 4a. A similar $16 \bar{e}$ ruthenium iminophosphonamide 5 has also been recently reported to coordinate reversibly CO to form the unstable $\mathrm{CO}$ adduct $\left(\nu_{\mathrm{CO}}=1993 \mathrm{~cm}^{-1}\right)$ and to not react with $\mathrm{Cl}^{-}, \mathrm{PPh}_{3}$, and $\mathrm{P}(\mathrm{OPh})_{3} \cdot{ }^{26}$ In sharp contrast, the more electron-deficient arene ruthenium amidinate $\left[\left(\eta^{6}-\mathrm{C}_{6} \mathrm{H}_{6}\right)\right.$ $\left.\mathrm{Ru}\left\{\mathrm{PhC}\left(\mathrm{N}^{t} \mathrm{Bu}\right)_{2}\right\}\right]\left(\mathrm{BAr}_{4}^{\mathrm{F}}\right)$ readily forms the stable carbonyl complex $\left[\left(\eta^{6}-\mathrm{C}_{6} \mathrm{H}_{6}\right) \mathrm{Ru}(\mathrm{CO})\left\{\mathrm{PhC}\left(\mathrm{N}^{t} \mathrm{Bu}\right)_{2}\right\}\right]\left(\mathrm{BAr}_{4}^{\mathrm{F}}\right)$, in which the $\mathrm{CO}$ band is observed at a much higher frequency $\left(\nu_{\mathrm{CO}}=\right.$ $\left.2050 \mathrm{~cm}^{-1}\right) .{ }^{30}$ On the other hand, the carbonyl band in the arene ruthenium complex with the dianionic dithiolate ligand $\left[\left(\eta^{6}-\mathrm{C}_{6} \mathrm{Me}_{6}\right) \mathrm{Ru}(\mathrm{CO})(\mathrm{SXyl})_{2}\right]\left(\nu_{\mathrm{CO}}=1965 \mathrm{~cm}^{-1}\right)^{54}$ is close to that in the $\mathrm{CO}$ adduct of the iminophosphonamide $\mathbf{4 a}$ and hence indirectly evidences for the zwitterionic nature of the NPN-ligand. Apparently in cationic iminophosphonamides 4a-c the positive charge is predominantly located on the phosphorus atom rather than on the ruthenium atom and thus their electronic properties are more like those of neutral arene ruthenium complexes with dianionic ligands.

\section{ROMP polymerization of norbornene}

Half-sandwich arene ruthenium complexes with sterically bulky phosphanes have been shown earlier to be readily acces- 
Table 2 Experimental data for the ring-opening metathesis polymerization of norbornene catalyzed by complexes 3-4

\begin{tabular}{|c|c|c|c|c|}
\hline Complex & Monomer conv. ( $\%$ & Polymer yield (\%) & $M_{\mathrm{n}}\left(\mathrm{kg} \mathrm{mol}{ }^{-1}\right)$ & $M_{\mathrm{w}} / M_{\mathrm{n}}$ \\
\hline $3 a$ & 87 & 76 & 50 & 2.7 \\
\hline $3 \mathbf{b}$ & 93 & 82 & 36 & 2.5 \\
\hline $4 b$ & 98 & 79 & 341 & 1.55 \\
\hline $4 c$ & 10 & 6 & - & - \\
\hline
\end{tabular}

sible precatalysts for ring-opening metathesis polymerization of both strained (norbornene) and low-strain (cyclooctene) cycloolefins and their functionalized derivatives. ${ }^{55,56}$ Typically, the polymers obtained from norbornene had a numberaverage molecular weight $M_{\mathrm{n}}$ of $60-80 \times 10^{3}$ and a molecular weight distribution $M_{\mathrm{w}} / M_{\mathrm{n}}$ of 1.6. We have demonstrated that under the same catalytic conditions the complexes $\mathbf{3 a - c}$ and 4a,b activated by trimethylsilyldiazomethane (TMSD) catalyze the polymerization of norbornene, except for almost inactive 4c (Table 2).

The 18e complexes 3a-c produced polymers of low molecular weight $M_{\mathrm{n}}=36-50 \times 10^{3}$, which is close to the expected $M_{\mathrm{n}}=23.5 \times 10^{3}$ calculated from the catalyst/substrate ratio (1/250), meaning that all ruthenium centers are involved in catalysis. The molecular weight distribution is relatively wide: $M_{\mathrm{w}} / M_{\mathrm{n}}$ is $2.5-2.7$ for $3 \mathbf{a}, \mathbf{b}$ and is 6.9 for $3 \mathbf{c}$. The polydispersity of the polymer can be significantly improved when $16 \overline{\mathrm{e}}$ complexes $\mathbf{4 a , b}$ are employed. They yield polymers of a much higher molecular weight $M_{\mathrm{n}}=283-341 \times 10^{3}$, which is supposedly due to their limited solubility in chlorobenzene and hence only a minor fraction (about 10\%) of these cationic complexes can participate in the catalytic cycle. This assumption would mean that the actual activity of $\mathbf{4 a , b}$ is about ten times higher than that of $\mathbf{3 a , b}$. Both types of complexes give a considerable fraction (11-20\%) of low-weight oligomers soluble in methanol.

In the absence of TMSD the ruthenium iminophosphonamides studied are inactive. The actual catalytically active species in the ROMP of olefins are carbene complexes, which are typically generated in situ from the precatalysts and TMSD. Recently, the $16 \overline{\mathrm{e}}$ cationic ruthenium amidinate complexes have been reported to react with TMSD to result in migration of the $\mathrm{SiMe}_{3}$ group to the ruthenium atom and formation of the amidinato-carbene complexes, in which the carbene moiety is inserted into the RuNCN metallacycle. ${ }^{57}$ These amidinate complexes provided low activity in the ROMP polymerization of norbornene; higher activity was mentioned for polymerization of high-strain norbornadiene catalyzed by the $18 \bar{e}$ complex $\left[\left(\mathrm{C}_{6} \mathrm{H}_{6}\right) \operatorname{RuBr}\left\{\mathrm{MeC}\left(\mathrm{N}^{\mathrm{i}} \mathrm{Pr}\right)_{2}\right\}\right]$ although the detailed results were not published. ${ }^{32}$ Perhaps, a similar carbene inser- tion into the $\mathrm{Ru}-\mathrm{N}$ bond occurs in the NPN-precatalysts. ${ }^{58}$ Not surprisingly, the more electron rich iminophosphonamide arene ruthenium complexes $\mathbf{3 a}, \mathbf{b}$ and $\mathbf{4 a}, \mathbf{b}$ excel the corresponding ruthenium amidinates in the ROMP polymerization of norbornene. However, our attempts to involve them in the ROMP of low-strain cyclooctene were unsuccessful.

It is noteworthy that strongly electron-releasing $N$-methyl substituents drastically decrease the activity of the complexes $3 \mathbf{c}$ and $\mathbf{4 c}$. The negligible activity of the 16ē complex $4 \mathbf{c}$ could be a result of very efficient stabilization of the unsaturated ruthenium center to make it insusceptible to the reaction with the generated in situ carbene $\mathrm{CHSiMe}_{3}$ rather than of the solubility issues. The same can be attributed to the reduced activity of $3 \mathbf{c}$, which should partially dissociate in polar chlorobenzene to form stable $16 \overline{\mathrm{e}}$ cationic species (vide supra).

\section{Experimental}

\section{General procedures}

All manipulations were carried out using standard Schlenk techniques under an atmosphere of dry argon. Solvents were purified by standard methods and distilled prior to use. $\mathrm{Ph}_{2} \mathrm{PCl}$ and $\mathrm{Et}_{2} \mathrm{PCl}$ were distilled under high vacuum or at ambient pressure, respectively, prior to use; other commercially available compounds were used as received. ${ }^{1} \mathrm{H},{ }^{31} \mathrm{P}$ and ${ }^{13} \mathrm{C}$ NMR spectra were obtained on a Bruker AMX-400 spectrometer and referenced to the residual signals of deuterated solvent $\left({ }^{1} \mathrm{H}\right.$ and $\left.{ }^{13} \mathrm{C}\right)$, and to $85 \% \mathrm{H}_{3} \mathrm{PO}_{4}\left({ }^{31} \mathrm{P}\right.$, external standard). Elemental analyses were performed on a Carlo Erba $1106 \mathrm{CHN}$ analyzer. The following compounds were prepared according to described procedures: $\left[\mathrm{Ph}_{2} \mathrm{P}(\mathrm{NH}-p \text {-Tol })_{2}\right] \mathrm{Br}(\mathbf{1 a}),{ }^{36}$ $\left[\left(\eta^{6}-\mathrm{C}_{6} \mathrm{Me}_{6}\right) \mathrm{RuCl}_{2}\right]_{2},{ }^{59} \mathrm{Na}\left[\mathrm{B}\left(3,5-\mathrm{C}_{6} \mathrm{H}_{3}\left(\mathrm{CF}_{3}\right)_{2}\right)_{4}\right]\left(\mathrm{NaBAr}_{4}^{\mathrm{F}}{ }_{4}\right){ }^{60}$

Synthesis of $\left[\mathrm{Et}_{2} \mathrm{P}(\mathrm{NH}-\mathrm{p}-\mathrm{Tol})_{2}\right] \mathrm{Br}(\mathbf{1 b})$. To a solution of $\mathrm{Et}_{2} \mathrm{PCl}(2.67 \mathrm{~g}, 21.5 \mathrm{mmol})$ in $\mathrm{CH}_{2} \mathrm{Cl}_{2}(30 \mathrm{~mL})$ cooled to $0^{\circ} \mathrm{C}$ a solution of $\mathrm{Br}_{2}(1.10 \mathrm{~mL}, 21.5 \mathrm{mmol})$ in $\mathrm{CH}_{2} \mathrm{Cl}_{2}(30 \mathrm{~mL})$ was added dropwise. The reaction mixture was warmed to $20{ }^{\circ} \mathrm{C}$, stirred for $1.5 \mathrm{~h}$ and cooled again to $0{ }^{\circ} \mathrm{C}$. A solution of $p$-toluidine $(9.2 \mathrm{~g}, 86 \mathrm{mmol})$ in $\mathrm{CH}_{2} \mathrm{Cl}_{2}(50 \mathrm{~mL})$ was added to the reaction mixture and the resulting suspension was stirred over- 
night at $20^{\circ} \mathrm{C}$. The precipitate was filtered off and washed with $\mathrm{CH}_{2} \mathrm{Cl}_{2}(3 \times 20 \mathrm{~mL})$. The filtrate was evaporated to dryness and the oily product was stirred with ethyl acetate $(150 \mathrm{~mL})$ for $2 \mathrm{~h}$. The fine crystal formed was filtered off, washed with ethyl acetate $(3 \times 10 \mathrm{~mL})$ and dried in vacuo to yield $5.80 \mathrm{~g}$ of $\mathbf{1 b}$. The filtrate was concentrated to $30 \mathrm{~mL}$ and left overnight. The precipitated crystal was filtered off, washed with ethyl acetate $(3 \times$ $3 \mathrm{~mL}$ ) and dried in vacuo to give additionally $0.92 \mathrm{~g}$ of the product. The total yield was $6.72 \mathrm{~g}(82 \%)$. Anal. calcd for $\mathrm{C}_{18} \mathrm{H}_{26} \mathrm{BrN}_{2} \mathrm{P}: \mathrm{C}, 56.70 ; \mathrm{H}, 6.87 ; \mathrm{N}, 7.35 \%$. Found: C, 56.92; H, 6.96; N, 7.33\%. ${ }^{31} \mathrm{P}$ NMR $\left(\mathrm{CDCl}_{3}\right): \delta 50.4 .{ }^{1} \mathrm{H}$ NMR $\left(\mathrm{CDCl}_{3}\right)$ : $\delta 8.77\left(\mathrm{~d},{ }^{2} J_{\mathrm{HP}}=13.6,2 \mathrm{H}, \mathrm{NH}\right), 7.28\left(\mathrm{~d},{ }^{3} J=8.0,4 \mathrm{H}, \mathrm{C}_{6} \mathrm{H}_{4}\right), 6.85$ $\left(\mathrm{d},{ }^{3} \mathrm{~J}=8.0,4 \mathrm{H}, \mathrm{C}_{6} \mathrm{H}_{4}\right), 2.62\left(\mathrm{dq},{ }^{3} \mathrm{~J}_{\mathrm{HP}}=14.0,{ }^{3} \mathrm{~J}=7.6,4 \mathrm{H}\right.$, $\left.\mathrm{CH}_{2} \mathrm{CH}_{3}\right), 2.15\left(\mathrm{~s}, 6 \mathrm{H}, \mathrm{Me}_{\mathrm{Tol}}\right), 1.04\left(\mathrm{dt},{ }^{4} J_{\mathrm{HP}}=21.1,{ }^{3} \mathrm{~J}=7.6,6 \mathrm{H}\right.$, $\left.\mathrm{CH}_{2} \mathrm{CH}_{3}\right) .{ }^{13} \mathrm{C}$ NMR $\left(\mathrm{CDCl}_{3}\right): \delta 135.6\left(\right.$ br. s, i- $\left.\mathrm{C}_{\mathrm{Tol}}(\mathrm{N})\right), 133.3(\mathrm{~s}$, i- $\left.\mathrm{C}_{\mathrm{Tol}}(\mathrm{Me})\right), 130.1$ (s, $\left.\beta-\mathrm{C}_{\mathrm{Tol}}\right), 119.7$ (br. s, $\left.\alpha-\mathrm{C}_{\mathrm{Tol}}\right), 20.6$ (s, $\left.\mathrm{Me}_{\mathrm{Tol}}\right), 14.7\left(\mathrm{~d},{ }^{1} J_{\mathrm{CP}}=80, \mathrm{CH}_{2} \mathrm{Me}\right), 4.8\left(\mathrm{~s}, \mathrm{CH}_{2} \mathrm{Me}\right)$.

Synthesis of $\left[\mathrm{Ph}_{2} \mathbf{P}(\mathbf{N H M e})_{2}\right] \mathbf{B r}(1 \mathrm{c})$. To a solution of $\mathrm{Ph}_{2} \mathrm{PCl}$ (4.35 mL, $24.0 \mathrm{mmol})$ in $\mathrm{CH}_{2} \mathrm{Cl}_{2}(50 \mathrm{~mL})$ at room temperature a solution of $\mathrm{Br}_{2}(1.23 \mathrm{~mL}, 24.0 \mathrm{mmol})$ in $\mathrm{CH}_{2} \mathrm{Cl}_{2}(15 \mathrm{~mL})$ was added dropwise. The reaction mixture was stirred for $1.5 \mathrm{~h}$ and cooled to $-50{ }^{\circ} \mathrm{C}$. A freshly prepared cold solution of dimethylamine in $\mathrm{CH}_{2} \mathrm{Cl}_{2}(3 \mathrm{M}, 75 \mathrm{~mL}, 225 \mathrm{mmol})$ was added to the reaction mixture and the resulting suspension was stirred overnight at $20{ }^{\circ} \mathrm{C}$. The precipitate was filtered off and washed with $\mathrm{CH}_{2} \mathrm{Cl}_{2}(3 \times 40 \mathrm{~mL})$. The filtrate was evaporated to dryness and then washed with benzene $(5 \times 20 \mathrm{~mL})$ and acetone $(5 \times$ $20 \mathrm{~mL}$ ). The white crystalline residue was dried in vacuo to yield $6.25 \mathrm{~g}$ of $1 \mathrm{c}(80 \%)$. Anal. calcd for $\mathrm{C}_{14} \mathrm{H}_{18} \mathrm{BrN}_{2} \mathrm{P}: \mathrm{C}, 51.71$; H, 5.58; N, 8.61\%. Found: C, 51.89; H, 5.74; N, 8.69\%. ${ }^{31} \mathrm{P}$ $\operatorname{NMR}\left(\mathrm{CDCl}_{3}\right): \delta 40.2 .{ }^{1} \mathrm{H} \mathrm{NMR}\left(\mathrm{CDCl}_{3}\right): \delta 7.97\left(\mathrm{dd},{ }^{3} \mathrm{JPP}_{\mathrm{HP}}=13.0\right.$, $\left.{ }^{3} J=8.2,4 \mathrm{H}, o-\mathrm{H}_{\mathrm{Ph}}\right), 7.51\left(\mathrm{dt},{ }^{3} J=7.6,{ }^{5} J_{\mathrm{HP}}=1.0,2 \mathrm{H}, p-\mathrm{H}_{\mathrm{Ph}}\right)$, $7.40\left(\mathrm{dt},{ }^{3} \mathrm{~J}=8.0,{ }^{4} J_{\mathrm{HP}}=3.6,4 \mathrm{H}, m-\mathrm{H}_{\mathrm{Ph}}\right), 6.61\left(\mathrm{dq},{ }^{2} J_{\mathrm{HP}}=16.2\right.$, $\left.{ }^{3} J=5.4,1 \mathrm{H}, \mathrm{NH}\right), 2.57\left(\mathrm{dd},{ }^{3} J_{\mathrm{HP}}=13.0,{ }^{3} J=5.4,6 \mathrm{H}, \mathrm{NMe}\right) .{ }^{13} \mathrm{C}$ $\operatorname{NMR}\left(\mathrm{CDCl}_{3}\right): \delta 123.0\left(\mathrm{~d},{ }^{1} J=126.0, \mathrm{i}-\mathrm{C}_{\mathrm{Ph}}\right), 132.4\left(\mathrm{~d},{ }^{2} J=11.2\right.$, $\left.o-\mathrm{C}_{\mathrm{Ph}}\right), 129.5\left(\mathrm{~d},{ }^{3} J=13.7, m-\mathrm{C}_{\mathrm{Ph}}\right), 133.9\left(\mathrm{~d},{ }^{4} J=2.7, p-\mathrm{C}_{\mathrm{Ph}}\right), 26.1$ (s, NMe).

Synthesis of $\left[\mathrm{Ph}_{2} \mathbf{P}(\mathbf{N}-\boldsymbol{p}\right.$-Tol)(NH-p-Tol)] (2a). To a suspension of $1 \mathrm{a}(2.00 \mathrm{~g}, 4.19 \mathrm{mmol})$ in benzene $(50 \mathrm{~mL})$ at room temperature neat $\mathrm{Et}_{2} \mathrm{NH}(0.45 \mathrm{~mL}, 4.35 \mathrm{mmol})$ was added. The mixture was stirred for $4 \mathrm{~h}$. The fine microcrystal was filtered off, washed with benzene $(2 \times 20 \mathrm{~mL})$ and discarded. The filtrate was evaporated to dryness, and the residue was washed with $10 \mathrm{~mL}$ of $\mathrm{Et}_{2} \mathrm{O} /$ hexane $=1 / 2(\mathrm{v}: \mathrm{v})$. Finally, it was redissolved in benzene; the hazy solution was filtered to remove the traces of the ammonium salts and then evaporated to give off-white powder. Yield $1.62 \mathrm{~g}(97 \%)$. Anal. calcd for $\mathrm{C}_{26} \mathrm{H}_{25} \mathrm{~N}_{2} \mathrm{P}: \mathrm{C}, 78.77 ; \mathrm{H}, 6.36 ; \mathrm{N}, 7.06 \%$. Found: $\mathrm{C}, 78.94 ; \mathrm{H}$, 6.49; N, 6.95\%. ${ }^{31} \mathrm{P}$ NMR $\left(\mathrm{CDCl}_{3}\right): \delta-3.5 .{ }^{1} \mathrm{H} \mathrm{NMR}\left(\mathrm{CDCl}_{3}\right)$ : $\delta 7.93\left(\mathrm{ddd},{ }^{3} J_{\mathrm{HP}}=12.4,{ }^{3} \mathrm{~J}=8.1,{ }^{4} J=1.8,4 \mathrm{H}, o-\mathrm{H}_{\mathrm{Ph}}\right), 7.39-7.51$ $\left(\mathrm{m}, 6 \mathrm{H}, m, p-\mathrm{H}_{\mathrm{Ph}}\right), 6.96\left(\mathrm{~d},{ }^{3} J=7.5,4 \mathrm{H}, \mathrm{C}_{6} \mathrm{H}_{4}\right), 6.92\left(\mathrm{~d},{ }^{3} J=7.5\right.$, $\left.4 \mathrm{H}, \mathrm{C}_{6} \mathrm{H}_{4}\right), 5.55$ (br. s, $\left.1 \mathrm{H}, \mathrm{NH}\right), 2.21\left(\mathrm{~s}, 6 \mathrm{H}, \mathrm{CH}_{3}\right) .{ }^{13} \mathrm{C}$ NMR $\left(\mathrm{C}_{6} \mathrm{D}_{6}\right): \delta 132.7\left(\mathrm{~d},{ }^{1} J=130.6, \mathrm{i}-\mathrm{C}_{\mathrm{Ph}}\right), 132.2\left(\mathrm{~d},{ }^{2} J=9.1, o-\mathrm{C}_{\mathrm{Ph}}\right)$, 131.3 (s, $p-\mathrm{C}_{\mathrm{Ph}}$ ), 129.8 (s, $\beta-\mathrm{C}_{\mathrm{Tol}}$ ), 128.9 (br. s, i- $\mathrm{C}_{\mathrm{Tol}}(\mathrm{Me})$ ), 128.5 (d, ${ }^{3} J=12.9, m-\mathrm{C}_{\mathrm{Ph}}$ ), 121.3 (br. d, ${ }^{3} J=11.8, \alpha-\mathrm{C}_{\mathrm{Tol}}$ ), 20.5 $\left(\mathrm{s}, \mathrm{Me}_{\mathrm{Tol}}\right)$.
Synthesis of $\left[\mathrm{Et}_{2} \mathbf{P}(\mathbf{N}-\boldsymbol{p}\right.$-Tol)(NH-p-Tol)] (2b). To a solution of $1 \mathbf{b}(0.76 \mathrm{~g}, 2.0 \mathrm{mmol})$ in benzene $(30 \mathrm{~mL})$ at room temperature a $2.0 \mathrm{M}$ solution of NaHMDS $(1.0 \mathrm{~mL}, 2.0 \mathrm{mmol})$ in THF was added and the mixture was stirred for $2 \mathrm{~h}$. The precipitate of $\mathrm{NaBr}$ was filtered off and washed with benzene $(3 \times 5 \mathrm{~mL})$. The filtrate was evaporated to dryness and the oily residue was washed with hexane $(2 \times 3 \mathrm{~mL})$ to give quantitatively the product. For an analytical purity the product was recrystallized from warm diethyl ether. Yield $0.55 \mathrm{~g}(92 \%)$. Anal. calcd for $\mathrm{C}_{18} \mathrm{H}_{25} \mathrm{~N}_{2} \mathrm{P}: \mathrm{C}, 71.97 ; \mathrm{H}, 8.39 ; \mathrm{N}, 9.33 \%$. Found: C, 71.95; H, 8.41; N, 9.27\%. ${ }^{31} \mathrm{P}$ NMR $\left(\mathrm{CDCl}_{3}\right): \delta 23.3 .{ }^{1} \mathrm{H}$ NMR $\left(\mathrm{CDCl}_{3}\right)$ : $\delta 6.96$ (br. s, $8 \mathrm{H}, \mathrm{C}_{6} \mathrm{H}_{4}$ ), 3.85 (br. s, $1 \mathrm{H}, \mathrm{NH}$ ), 2.24 (s, $6 \mathrm{H}, \mathrm{CH}_{3}$ ), $2.07\left(\mathrm{dq},{ }^{2} J_{\mathrm{HP}}=14.4,{ }^{3} \mathrm{~J}=7.6,4 \mathrm{H}, \mathrm{CH}_{2} \mathrm{CH}_{3}\right), 1.12\left(\mathrm{dt},{ }^{3} J_{\mathrm{HP}}=\right.$ $\left.18.5,{ }^{3} \mathrm{~J}=7.6,6 \mathrm{H}, \mathrm{CH}_{2} \mathrm{CH}_{3}\right) .{ }^{13} \mathrm{C}$ NMR $\left(\mathrm{C}_{6} \mathrm{D}_{6}\right): \delta 144.5$ (br. s, i- $\left.\mathrm{C}_{\mathrm{Tol}}(\mathrm{N})\right), 128.6\left(\mathrm{~s}, \mathrm{i}-\mathrm{C}_{\mathrm{Tol}}(\mathrm{Me})\right), 129.9\left(\mathrm{~s}, \beta-\mathrm{C}_{\mathrm{Tol}}\right), 121.1\left(\mathrm{~d},{ }^{3} J_{\mathrm{CP}}=\right.$ $\left.12, \alpha-\mathrm{C}_{\mathrm{Tol}}\right), 20.5\left(\mathrm{~s}, \mathrm{Me}_{\mathrm{Tol}}\right), 18.9\left(\mathrm{~d},{ }^{1} J_{\mathrm{CP}}=87, \mathrm{CH}_{2} \mathrm{Me}\right), 6.4(\mathrm{~d}$, ${ }^{2} J_{\mathrm{CP}}=3, \mathrm{CH}_{2} \mathrm{Me}$ ).

Synthesis of $\left[\mathrm{Ph}_{2} \mathrm{P}(\mathrm{NMe})(\mathrm{NHMe})\right](2 \mathrm{c})$. To a suspension of $1 \mathrm{c}$ $(1.00 \mathrm{~g}, 3.05 \mathrm{mmol})$ in THF $(50 \mathrm{~mL})$ at room temperature a 2.0 M solution of NaHMDS $(1.5 \mathrm{~mL}, 3.0 \mathrm{mmol})$ in THF was added and the mixture was stirred for $18 \mathrm{~h}$. The precipitate of $\mathrm{NaBr}$ was filtered off and washed with THF $(3 \times 5 \mathrm{~mL})$. The filtrate was evaporated to dryness and the oily residue was washed with hexane $(2 \times 3 \mathrm{~mL})$ and dried in vacuo to give a colorless glassy solid. Yield $0.72 \mathrm{~g}(96 \%) .{ }^{31} \mathrm{P}$ NMR $\left(\mathrm{CDCl}_{3}\right): \delta 12.4$. ${ }^{1} \mathrm{H}$ NMR $\left(\mathrm{THF}-d_{8}\right): \delta 7.95$ (ddd, ${ }^{3} \mathrm{JHP}_{\mathrm{HP}}=11.2,{ }^{3} J=7.6,{ }^{4} J=2.0,4 \mathrm{H}$, $\left.o-\mathrm{H}_{\mathrm{Ph}}\right), 7.45-7.52\left(\mathrm{~m}, 6 \mathrm{H}, m, p-\mathrm{H}_{\mathrm{Ph}}\right), 2.81\left(\mathrm{~d},{ }^{3} J_{\mathrm{HP}}=18.0,6 \mathrm{H}\right.$, $\left.\mathrm{CH}_{3}\right)$.

Synthesis of $\left[\left(\eta^{6}-\mathrm{C}_{6} \mathrm{Me}_{6}\right) \operatorname{RuCl}\left\{\mathrm{R}_{2} \mathrm{P}(\mathrm{N}-p-\mathrm{Tol})_{2}\right\}\right](3 \mathrm{a}, \mathbf{b})$. General procedure. To a solution of $2 \mathrm{a}(0.80 \mathrm{~g}, 2.02 \mathrm{mmol})$ in benzene $(60 \mathrm{~mL})$ a $2.0 \mathrm{M}$ solution of NaHMDS in THF $(1.10 \mathrm{~mL}$, $2.20 \mathrm{mmol}$ ) was added and the resulting solution was stirred for $1 \mathrm{~h}$. Then the solid $\left[\left(\eta^{6}-\mathrm{C}_{6} \mathrm{Me}_{6}\right) \mathrm{RuCl}_{2}\right]_{2}(0.67 \mathrm{~g}, 1.00 \mathrm{mmol})$ was added and the reaction mixture was stirred overnight. The solvent was removed in vacuo, the residue was washed with hexane $(2 \times 10 \mathrm{~mL})$ and extracted with $\mathrm{CH}_{2} \mathrm{Cl}_{2}(100 \mathrm{~mL})$. The filtrate was diluted with $10 \mathrm{~mL}$ of benzene and slowly evaporated to 3-5 $\mathrm{mL}$. The precipitated brick-red crystal was filtered off, washed with benzene $(2 \mathrm{~mL}), \mathrm{Et}_{2} \mathrm{O}(10 \mathrm{~mL})$ and dried under vacuum. Yield $1.20 \mathrm{~g}$ (86\%). Anal. calcd for $\mathrm{C}_{38} \mathrm{H}_{42} \mathrm{ClN}_{2} \mathrm{PRu}$ : C, 65.74; H, 6.10\%. Found: C, 65.87; H, 6.29\%. ${ }^{31} \mathrm{P} \mathrm{NMR}\left(\mathrm{CDCl}_{3}\right): \delta 43.9 .{ }^{1} \mathrm{H}$ NMR $\left(\mathrm{CDCl}_{3}\right): \delta 7.76$ (br. $\mathrm{dd},{ }^{3} J_{\mathrm{HP}}=12,{ }^{3} \mathrm{~J}=8,4 \mathrm{H}, o-\mathrm{H}_{\mathrm{Ph}}$ ), 7.44 (br. t, $2 \mathrm{H}, p-\mathrm{H}_{\mathrm{Ph}}$ ), 7.33 (br. $\left.\mathrm{m}, 4 \mathrm{H}, m-\mathrm{H}_{\mathrm{Ph}}\right), 6.88\left(\mathrm{~d},{ }^{3} \mathrm{~J}=8.0,4 \mathrm{H}, \mathrm{C}_{6} \mathrm{H}_{4}\right), 6.78\left(\mathrm{~d},{ }^{3} \mathrm{~J}=8.0,4 \mathrm{H}\right.$, $\left.\mathrm{C}_{6} \mathrm{H}_{4}\right), 2.10\left(\mathrm{~s}, 6 \mathrm{H}, \mathrm{Me}_{\mathrm{Tol}}\right), 1.95\left(\mathrm{~s}, 18 \mathrm{H}, \mathrm{C}_{6} \mathrm{Me}_{6}\right) .{ }^{1} \mathrm{H} \mathrm{NMR}$ $\left(\mathrm{C}_{6} \mathrm{D}_{6}\right): \delta 8.07\left(\mathrm{~m}, 2 \mathrm{H}, o-\mathrm{H}_{\mathrm{Ph}}\right), 7.91\left(\mathrm{ddd},{ }^{3} J_{\mathrm{HP}}=11.2,{ }^{3} \mathrm{~J}=8.0\right.$, $\left.{ }^{3} J=1.6,2 \mathrm{H}, o^{\prime}-\mathrm{H}_{\mathrm{Ph}}\right), 7.35\left(\mathrm{dd},{ }^{3} J=8.0,{ }^{4} J_{\mathrm{HP}}=1.2,4 \mathrm{H}, \mathrm{C}_{6} \mathrm{H}_{4}\right)$, $7.23\left(\mathrm{~m}, 3 \mathrm{H},\left(p^{\prime}+m\right)-\mathrm{H}_{\mathrm{Ph}}\right), 6.89\left(\mathrm{~d},{ }^{3} J=8.0,4 \mathrm{H}, \mathrm{C}_{6} \mathrm{H}_{4}\right), 6.73(\mathrm{~m}$, $\left.3 \mathrm{H},\left(p+m^{\prime}\right)-\mathrm{H}_{\mathrm{Ph}}\right), 2.10\left(\mathrm{~s}, 6 \mathrm{H}, \mathrm{Me}_{\mathrm{Tol}}\right), 1.80\left(\mathrm{~s}, 18 \mathrm{H}, \mathrm{C}_{6} \mathrm{Me}_{6}\right) \cdot{ }^{13} \mathrm{C}$ NMR $\left(\mathrm{CDCl}_{3}\right): \delta 144.6\left(\mathrm{~d},{ }^{2} J_{\mathrm{CP}}=4.4, \mathrm{i}-\mathrm{C}_{\mathrm{Tol}}(\mathrm{N})\right), 133.2\left(\mathrm{~d},{ }^{2} J_{\mathrm{CP}}=\right.$ $\left.10.9, o-\mathrm{C}_{\mathrm{Ph}}\right), 131.4\left(\mathrm{~d},{ }^{4} J_{\mathrm{CP}}=2.0, p-\mathrm{C}_{\mathrm{Ph}}\right), 128.5\left(\mathrm{~s}, \beta-\mathrm{C}_{\mathrm{Tol}}\right), 127.9$ (s, i- $\left.\mathrm{C}_{\mathrm{Tol}}(\mathrm{Me})\right), 127.6\left(\mathrm{~d},{ }^{3} J_{\mathrm{CP}}=12.7, m-\mathrm{C}_{\mathrm{Ph}}\right), 125.1\left(\mathrm{~d},{ }^{3} \mathrm{~J}=9.3\right.$, $\left.\alpha-\mathrm{C}_{\mathrm{Tol}}\right), 89.2$ (s, $C_{6} \mathrm{Me}_{6}$ ), 20.5 (s, Me $\mathrm{Tol}_{\mathrm{Tol}}$ ), 16.2 (s, $\mathrm{C}_{6} \mathrm{Me}_{6}$ ). UV-vis $\left(\mathrm{CH}_{2} \mathrm{Cl}_{2} ; \lambda_{\max }, \mathrm{nm} ; \varepsilon, \mathrm{M}^{-1} \mathrm{~cm}^{-1}\right): 450$ (900).

Analogously, from $2 \mathbf{b}(0.51 \mathrm{~g}, 1.70 \mathrm{mmol})$ in THF $(50 \mathrm{~mL})$, NaHMDS (2.0 M, $0.90 \mathrm{ml}, 1.80 \mathrm{mmol})$ and $\left[\left(\eta^{6}-\mathrm{C}_{6} \mathrm{Me}_{6}\right) \mathrm{RuCl}_{2}\right]_{2}$ 
(0.56 g, $0.85 \mathrm{mmol}$ ), complex 3b was obtained. The product was purified by precipitation from a benzene solution (3-5 $\mathrm{mL})$ with hexane (10-15 $\mathrm{mL}$ ) and further recrystallized from $\mathrm{Et}_{2} \mathrm{O}$. Yield $0.74 \mathrm{~g}(73 \%)$. Anal. calcd for $\mathrm{C}_{30} \mathrm{H}_{42} \mathrm{ClN}_{2} \mathrm{PRu}$ : C, 60.24; H, 7.08\%. Found: C, 60.37; H, 7.11\%. ${ }^{31} \mathrm{P}$ NMR $\left(\mathrm{CDCl}_{3}\right): \delta 72.4 .{ }^{1} \mathrm{H} \mathrm{NMR}\left(\mathrm{CDCl}_{3}\right): \delta 7.04\left(\mathrm{~d},{ }^{3} J=8.0,4 \mathrm{H}, \mathrm{C}_{6} \mathrm{H}_{4}\right)$, $6.89\left(\mathrm{~d},{ }^{3} \mathrm{~J}=8.0,4 \mathrm{H}, \mathrm{C}_{6} \mathrm{H}_{4}\right), 2.23\left(\mathrm{~s}, 6 \mathrm{H}, \mathrm{Me}_{\mathrm{Tol}}\right), 1.89$ (s, $18 \mathrm{H}$, $\left.\mathrm{C}_{6} \mathrm{Me}_{6}\right), 1.77\left(\mathrm{dq},{ }^{2} \mathrm{JHP}_{\mathrm{HP}}=11.7,{ }^{3} \mathrm{~J}=7.6,4 \mathrm{H}, \mathrm{CH}_{2} \mathrm{CH}_{3}\right), 1.05$ (dt, $\left.{ }^{3} J_{\mathrm{HP}}=16.2,{ }^{3} \mathrm{~J}=7.6,6 \mathrm{H}, \mathrm{CH}_{2} \mathrm{CH}_{3}\right) .{ }^{1} \mathrm{H}$ NMR $\left(\mathrm{C}_{6} \mathrm{D}_{6}\right): \delta 7.48(\mathrm{~d}$, $\left.{ }^{3} J=7.7,4 \mathrm{H}, \mathrm{C}_{6} \mathrm{H}_{4}\right), 7.11\left(\mathrm{~d},{ }^{3} J=7.7,4 \mathrm{H}, \mathrm{C}_{6} \mathrm{H}_{4}\right), 2.33(\mathrm{~s}, 6 \mathrm{H}$, $\mathrm{Me}_{\mathrm{Tol}}$ ), 2.17 (br. dq, ${ }^{2} J_{\mathrm{HP}}=14.4,{ }^{3} J=7.8,2 \mathrm{H}, \mathrm{CH}_{2}{ }^{\prime} \mathrm{CH}_{3}$ ), 1.86 (s, $18 \mathrm{H}, \mathrm{C}_{6} \mathrm{Me}_{6}$ ), 1.47 (br. dt, ${ }^{3} J_{\mathrm{HP}}=15.6,{ }^{3} \mathrm{~J}=7.2,3 \mathrm{H}, \mathrm{CH}_{2} \mathrm{CH}_{3}$ ), 1.31 (br. dq, ${ }^{2} J_{\mathrm{HP}}=14.4,{ }^{3} J=7.2,2 \mathrm{H}, \mathrm{CH}_{2} \mathrm{CH}_{3}$ ), 0.54 (br. dt, $\left.{ }^{3} J_{\mathrm{HP}}=15.6,{ }^{3} \mathrm{~J}=7.8,3 \mathrm{H}, \mathrm{CH}_{2} \mathrm{CH}_{3}{ }^{\prime}\right) \cdot{ }^{13} \mathrm{C} \mathrm{NMR}\left(\mathrm{CDCl}_{3}\right): \delta 145.1$ $\left(\mathrm{d},{ }^{2} J_{\mathrm{CP}}=4.0\right.$, i- $\left.\mathrm{C}_{\mathrm{Tol}}(\mathrm{N})\right), 128.9\left(\mathrm{~s}, \mathrm{i}-\mathrm{C}_{\mathrm{Tol}}(\mathrm{Me})\right), 128.8\left(\mathrm{~s}, \beta-\mathrm{C}_{\mathrm{Tol}}\right)$, $126.1\left(\mathrm{~d},{ }^{3} J_{\mathrm{CP}}=6.7, \alpha-\mathrm{C}_{\mathrm{Tol}}\right), 88.7\left(\mathrm{~s}, C_{6} \mathrm{Me}_{6}\right), 25.7\left(\mathrm{~d},{ }^{1} J_{\mathrm{CP}}=54.8\right.$, $\mathrm{CH}_{2} \mathrm{Me}$ ), 20.6 (s, $\mathrm{Me}_{\mathrm{Tol}}$ ), 15.9 (s, $\mathrm{C}_{6} \mathrm{Me}_{6}$ ), 6.5 (d, ${ }^{2} J_{\mathrm{CP}}=4.8$, $\left.\mathrm{CH}_{2} \mathrm{Me}\right)$. UV-vis $\left(\mathrm{CH}_{2} \mathrm{Cl}_{2} ; \lambda_{\text {max }}, \mathrm{nm} ; \varepsilon, \mathrm{M}^{-1} \mathrm{~cm}^{-1}\right): 450$ (940).

Synthesis of $\left[\left(\eta^{6}-\mathrm{C}_{6} \mathrm{Me}_{6}\right) \operatorname{RuCl}\left\{\mathrm{Ph}_{2} \mathrm{P}(\mathrm{NMe})_{2}\right\}\right]$ (3c). To a solution of $1 \mathrm{c}(0.76 \mathrm{~g}, 2.3 \mathrm{mmol})$ in THF $(50 \mathrm{~mL})$ a $2.0 \mathrm{M}$ solution of NaHMDS in THF $(1.20 \mathrm{~mL}, 2.40 \mathrm{mmol})$ was added and the resulting solution was stirred for $3 \mathrm{~h}$. The precipitate of $\mathrm{NaBr}$ was removed by filtration, the filtrate was treated again with a 2.0 M solution of NaHMDS (1.2 mL, $2.4 \mathrm{mmol})$ and stirred for an extra $3 \mathrm{~h}$. Then the solid $\left[\left(\eta^{6}-\mathrm{C}_{6} \mathrm{Me}_{6}\right) \mathrm{RuCl}_{2}\right]_{2}(0.77 \mathrm{~g}$, $1.15 \mathrm{mmol}$ ) was added and the reaction mixture was stirred overnight. The solvent was removed in vacuo, and the residue was washed with hexane $(2 \times 10 \mathrm{~mL})$ and extracted with benzene $(40 \mathrm{~mL})$. The filtrate was diluted with $40 \mathrm{~mL}$ of hexane, and the flocculated black impurities were filtered off. The solution was evaporated to 5-7 $\mathrm{mL}$ and set for crystallization in a fridge at $-20{ }^{\circ} \mathrm{C}$. The precipitated dark-red crystalline was filtered off, washed with cold hexane $(5 \mathrm{~mL})$ and dried under vacuum. Yield $0.77 \mathrm{~g}(62 \%)$. Anal. calcd for $\mathrm{C}_{26} \mathrm{H}_{34} \mathrm{ClN}_{2} \mathrm{PRu}: \mathrm{C}, 57.61 ; \mathrm{H}, 6.32 \%$. Found: C, 57.40; $\mathrm{H}$, 6.38\%. ${ }^{31} \mathrm{P}$ NMR $\left(\mathrm{C}_{6} \mathrm{D}_{6}\right): \delta$ 59.8. ${ }^{31} \mathrm{P} \mathrm{NMR}\left(\mathrm{CDCl}_{3}\right): \delta 76.9 .{ }^{1} \mathrm{H}$ NMR $\left(\mathrm{C}_{6} \mathrm{D}_{6}\right): \delta 8.00$ (br. s, $\left.2 \mathrm{H}, o-\mathrm{H}_{\mathrm{Ph}}\right), 7.69$ (br. s, $2 \mathrm{H}, o-\mathrm{H}_{\mathrm{Ph}}$ ), 7.21 (br. s, $\left.3 \mathrm{H},(m+p)-\mathrm{H}_{\mathrm{Ph}}\right), 7.12$ (br. s, $\left.1 \mathrm{H}, p^{\prime}-\mathrm{H}_{\mathrm{Ph}}\right), 7.05$ (br. $\mathrm{s}$, $\left.2 \mathrm{H}, m^{\prime}-\mathrm{H}_{\mathrm{Ph}}\right), 2.74\left(\mathrm{~d},{ }^{3} J_{\mathrm{HP}}=19.2,6 \mathrm{H}, \mathrm{NMe}\right), 1.84(\mathrm{~s}, 18 \mathrm{H}$, $\left.\mathrm{C}_{6} \mathrm{Me}_{6}\right) \cdot{ }^{1} \mathrm{H} \mathrm{NMR}\left(\mathrm{CDCl}_{3}\right): \delta 7.55\left(\mathrm{td},{ }^{3} J=7.2,{ }^{5} J_{\mathrm{HP}}=1.2,2 \mathrm{H}\right.$, $\left.p-\mathrm{H}_{\mathrm{Ph}}\right), 7.44\left(\mathrm{td},{ }^{3} J=8.0,{ }^{4} J_{\mathrm{HP}}=2.8,4 \mathrm{H}, m-\mathrm{H}_{\mathrm{Ph}}\right), 7.26\left(\mathrm{dd},{ }^{3} J_{\mathrm{HP}}=\right.$ $\left.10.4,{ }^{3} J=8.0,4 \mathrm{H}, o-\mathrm{H}_{\mathrm{Ph}}\right), 2.71\left(\mathrm{~d},{ }^{3} J_{\mathrm{HP}}=19.2,6 \mathrm{H}, \mathrm{NMe}\right), 2.27$ $\left(\mathrm{s}, 18 \mathrm{H}, \mathrm{C}_{6} \mathrm{Me}_{6}\right) \cdot{ }^{13} \mathrm{C} \mathrm{NMR}\left(\mathrm{C}_{6} \mathrm{D}_{6}\right): \delta 140.6\left(\mathrm{~d},{ }^{1} J_{\mathrm{CP}}=104.0\right.$, i- $\mathrm{C}_{\mathrm{Ph}}$ ), $132.2\left(\mathrm{~d},{ }^{1} J_{\mathrm{CP}}=58.2\right.$, i- $\left.\mathrm{C}_{\mathrm{Ph}^{\prime}}\right), 134.9$ (br. s., $o-\mathrm{C}_{\mathrm{Ph}}$ ), 131.3 (br. s., $\left.p-\mathrm{C}_{\mathrm{Ph}}\right), 130.5$ (br. s., $\left.\left(m+m^{\prime}\right)-\mathrm{C}_{\mathrm{Ph}}\right), 130.2$ (br. s., $\left(o^{\prime}+\right.$ $\left.\left.p^{\prime}\right)-\mathrm{C}_{\mathrm{Ph}}\right), 88.7$ (s, $\left.C_{6} \mathrm{Me}_{6}\right), 32.9$ (s, NMe), 15.6 (s, $\left.\mathrm{C}_{6} M e_{6}\right)$. UV-vis (toluene; $\lambda_{\max }, \mathrm{nm} ; \varepsilon, \mathrm{M}^{-1} \mathrm{~cm}^{-1}$ ): 410 (1550).

Synthesis of $\left[\left(\eta^{6}-\mathrm{C}_{6} \mathbf{M e}_{6}\right) \mathbf{R u}\left\{\mathrm{R}_{2} \mathrm{P}(\mathrm{N}-\mathrm{p} \text {-Tol })_{2}\right\}\right](\mathrm{X})\left(\mathbf{4 a}, \mathrm{X}=\mathbf{P F}_{6}\right.$; $4 \mathbf{b}, \mathrm{X}=\mathrm{BF}_{4} ; \mathbf{4 c}, \mathrm{X}=\mathrm{BAr}_{4}{ }_{4}$ ). General procedure. (a) To a solution of $3 \mathrm{a}(0.46 \mathrm{~g}, 0.66 \mathrm{mmol})$ in $\mathrm{CH}_{2} \mathrm{Cl}_{2}(30 \mathrm{ml})$, solid $\mathrm{AgPF}_{6}$ $(0.18 \mathrm{~g}, 0.72 \mathrm{mmol})$ was added, the color immediately changed from red to deep violet. The reaction mixture was stirred for $3 \mathrm{~h}$ and then filtered through a plug of Celite. The solution was concentrated to $2 \mathrm{~mL}$, further addition of $\mathrm{Et}_{2} \mathrm{O}(10 \mathrm{~mL})$ resulted in the precipitation of a product, which was filtered off, washed with $\mathrm{Et}_{2} \mathrm{O}(2 \times 5 \mathrm{~mL})$ and dried under vacuum.
Yield of $4 \mathrm{a} 0.51 \mathrm{~g}(96 \%)$. Anal. calcd for $\mathrm{C}_{38} \mathrm{H}_{42} \mathrm{~F}_{6} \mathrm{~N}_{2} \mathrm{P}_{2} \mathrm{Ru}$ : C, 56.78; H, 5.27\%. Found: C, 56.69; H, 5.12\%. ${ }^{31} \mathrm{P}$ NMR $\left(\mathrm{CDCl}_{3}\right)$ : 71.9, -144.4 (sept, $\left.J_{\mathrm{PF}}=707, \mathrm{PF}_{6}{ }^{-}\right) .{ }^{1} \mathrm{H}$ NMR $\left(\mathrm{CDCl}_{3}\right): \delta 7.64$ $\left(\mathrm{td},{ }^{3} J=7.6,{ }^{5} J_{\mathrm{HP}}=1.2,2 \mathrm{H}, p-\mathrm{H}_{\mathrm{Ph}}\right), 7.49\left(\mathrm{td},{ }^{3} J=7.6,{ }^{4} J_{\mathrm{HP}}=3.2\right.$, $\left.4 \mathrm{H}, m-\mathrm{H}_{\mathrm{Ph}}\right), 7.38\left(\mathrm{dd},{ }^{3} J_{\mathrm{HP}}=12.0,{ }^{3} J=7.2,4 \mathrm{H}, o-\mathrm{H}_{\mathrm{Ph}}\right), 7.02(\mathrm{~d}$, $\left.{ }^{3} J=7.6,4 \mathrm{H}, \mathrm{C}_{6} \mathrm{H}_{4}\right), 6.68\left(\mathrm{~d},{ }^{3} J=7.6,4 \mathrm{H}, \mathrm{C}_{6} \mathrm{H}_{4}\right), 2.28(\mathrm{~s}, 6 \mathrm{H}$, $\left.\mathrm{Me}_{\mathrm{Tol}}\right), 2.08\left(\mathrm{~s}, 18 \mathrm{H}, \mathrm{C}_{6} \mathrm{Me}_{6}\right) \cdot{ }^{13} \mathrm{C} \mathrm{NMR}\left(\mathrm{CD}_{2} \mathrm{Cl}_{2}\right): \delta 141.6\left(\mathrm{~d},{ }^{2} J_{\mathrm{CP}}\right.$ $\left.=2, \mathrm{i}-\mathrm{C}_{\mathrm{Tol}}(\mathrm{N})\right), 135.3\left(\mathrm{~s}, \mathrm{i}-\mathrm{C}_{\mathrm{Tol}}(\mathrm{Me})\right), 134.2\left(\mathrm{~d},{ }^{4} J_{\mathrm{CP}}=2.3, p-\mathrm{C}_{\mathrm{Ph}}\right)$, $132.0\left(\mathrm{~d},{ }^{2} J_{\mathrm{CP}}=10.6, o-\mathrm{C}_{\mathrm{Ph}}\right), 130.1\left(\mathrm{~s}, \beta-\mathrm{C}_{\mathrm{Tol}}\right), 129.3\left(\mathrm{~d},{ }^{3} J_{\mathrm{CP}}=\right.$ 12.4, $m-\mathrm{C}_{\mathrm{Ph}}$ ), $126.3\left(\mathrm{~d},{ }^{3} J=6.2, \alpha-\mathrm{C}_{\mathrm{Tol}}\right), 126.2\left(\mathrm{~d},{ }^{1} J=90.5\right.$, i-C $\mathrm{Ch}_{\mathrm{Ph}}$ ), 89.9 (s, $C_{6} \mathrm{Me}_{6}$ ), 20.8 (s, Me $\mathrm{Tol}_{\text {) }}$ ), 16.5 (s, $\mathrm{C}_{6} \mathrm{Me}_{6}$ ). UV-vis $\left(\mathrm{CH}_{2} \mathrm{Cl}_{2} ; \lambda_{\max }, \mathrm{nm} ; \varepsilon, \mathrm{M}^{-1} \mathrm{~cm}^{-1}\right): 540$ (1320).

Analogously, from $3 \mathbf{b}(0.45 \mathrm{~g}, 0.75 \mathrm{mmol})$ and $\mathrm{AgBF}_{4}$ (0.15 g, $0.77 \mathrm{mmol}$ ), complex $4 \mathbf{b}$ was obtained (0.46 g, 93\%). Anal. calcd for $\mathrm{C}_{30} \mathrm{H}_{42} \mathrm{BF}_{4} \mathrm{~N}_{2} \mathrm{PRu}$ : C, 55.48; H, 6.52\%. Found: C, 55.61; H, 6.44\%. ${ }^{31} \mathrm{P}$ NMR $\left(\mathrm{CDCl}_{3}\right): \delta 102.3 .{ }^{1} \mathrm{H} \mathrm{NMR}\left(\mathrm{CDCl}_{3}\right): \delta$ $7.14\left(\mathrm{~d},{ }^{3} J=6.0,4 \mathrm{H}, \mathrm{C}_{6} \mathrm{H}_{4}\right), 6.91\left(\mathrm{~d},{ }^{3} J=6.0,4 \mathrm{H}, \mathrm{C}_{6} \mathrm{H}_{4}\right), 2.31$ (s, $6 \mathrm{H}, \mathrm{Me}_{\mathrm{Tol}}$ ), 2.02 (s, $18 \mathrm{H}, \mathrm{C}_{6} \mathrm{Me}_{6}$ ), 1.59 (br. dq, ${ }^{2} J_{\mathrm{HP}}=10,{ }^{3} \mathrm{~J}=8$, $4 \mathrm{H}, \mathrm{CH}_{2} \mathrm{CH}_{3}$ ), 0.99 (br. dt, $\left.{ }^{3} J_{\mathrm{HP}}=16,{ }^{3} \mathrm{~J}=8,6 \mathrm{H}, \mathrm{CH}_{2} \mathrm{CH}_{3}\right) \cdot{ }^{13} \mathrm{C}$ NMR $\left(\mathrm{CDCl}_{3}\right): \delta 141.4\left(\mathrm{~d},{ }^{2} J_{\mathrm{CP}}=4.0, \mathrm{i}-\mathrm{C}_{\mathrm{Tol}}(\mathrm{N})\right), 134.9\left(\mathrm{~d},{ }^{5} J_{\mathrm{CP}}=\right.$ 2.0, i- $\left.\mathrm{C}_{\mathrm{Tol}}(\mathrm{Me})\right), 130.3\left(\mathrm{~s}, \beta-\mathrm{C}_{\mathrm{Tol}}\right), 125.7\left(\mathrm{~d},{ }^{3} J_{\mathrm{CP}}=5.2, \alpha-\mathrm{C}_{\mathrm{Tol}}\right)$, $89.2\left(\mathrm{~s}, C_{6} \mathrm{Me}_{6}\right.$ ), 20.6 (s, $\mathrm{Me}_{\mathrm{Tol}}$ ), 19.8 (d, ${ }^{1} J_{\mathrm{CP}}=53.6, \mathrm{CH}_{2} \mathrm{Me}$ ), $16.3\left(\mathrm{~s}, \mathrm{C}_{6} M e_{6}\right), 5.2\left(\mathrm{~d},{ }^{2} J_{\mathrm{CP}}=5.4, \mathrm{CH}_{2} \mathrm{Me}\right)$. UV-vis $\left(\mathrm{CH}_{2} \mathrm{Cl}_{2} ; \lambda_{\max }\right.$, $\left.\mathrm{nm} ; \varepsilon, \mathrm{M}^{-1} \mathrm{~cm}^{-1}\right)$ : 540 (1410).

Analogously, from $3 \mathrm{c}(0.14 \mathrm{~g}, 0.26 \mathrm{mmol})$ and $\mathrm{NaBAr}_{4}^{\mathrm{F}}$ (0.23 g, $0.27 \mathrm{mmol}$ ), complex 4c was obtained (0.34 g, 96\%). Anal. calcd for $\mathrm{C}_{58} \mathrm{H}_{46} \mathrm{BF}_{24} \mathrm{~N}_{2} \mathrm{PRu}$ : C, 50.86; $\mathrm{H}, 3.38 \%$. Found: C, 50.85; H, 3.34\%. ${ }^{31} \mathrm{P} \mathrm{NMR}\left(\mathrm{CDCl}_{3}\right): \delta 80.8 .{ }^{1} \mathrm{H}$ NMR $\left(\mathrm{CDCl}_{3}\right)$ : $\delta 7.71$ (br. s., $\left.8 \mathrm{H}, o-\mathrm{H}_{\mathrm{BARF}}\right), 7.60\left(\mathrm{ttd},{ }^{3} \mathrm{~J}=7.5,{ }^{4} \mathrm{~J}=1.5,{ }^{5} \mathrm{JPP}_{\mathrm{HP}}=\right.$ 1.4, $2 \mathrm{H}, p-\mathrm{H}_{\mathrm{Ph}}$ ), 7.50 (br. s., $4 \mathrm{H}, p-\mathrm{H}_{\mathrm{BARF}}$ ), $7.46\left(\mathrm{td},{ }^{3} J=7.5,{ }^{4} J_{\mathrm{HP}}\right.$ $\left.=3.0,4 \mathrm{H}, m-\mathrm{H}_{\mathrm{Ph}}\right), 7.25\left(\mathrm{dd},{ }^{3} J_{\mathrm{HP}}=12.9,{ }^{3} J=7.2,4 \mathrm{H}, o-\mathrm{H}_{\mathrm{Ph}}\right)$, $2.74\left(\mathrm{~d},{ }^{3} J_{\mathrm{HP}}=18.3,6 \mathrm{H}, \mathrm{NMe}\right), 2.27\left(\mathrm{~s}, 18 \mathrm{H}, \mathrm{C}_{6} \mathrm{Me}_{6}\right) \cdot{ }^{13} \mathrm{C} \mathrm{NMR}$ $\left(\mathrm{CDCl}_{3}\right): \delta 161.7\left(\mathrm{q},{ }^{1} J_{\mathrm{CB}}=49.8, \mathrm{i}-\mathrm{C}_{\mathrm{B}}\left(\mathrm{BAr}^{\mathrm{F}}\right)\right), 128.7\left(\mathrm{qq},{ }^{2} J_{\mathrm{CF}}=\right.$ 31.2, $\left.{ }^{3} J_{\text {Св }}=2.4, m-\mathrm{C}\left(\mathrm{BAr}^{\mathrm{F}}\right)\right), 117.4\left(\mathrm{~m}, o-\mathrm{C}\left(\mathrm{BAr}^{\mathrm{F}}\right)\right), 134.7$ (br. s, $\left.p-\mathrm{C}\left(\mathrm{BAr}^{\mathrm{F}}\right)\right), 124.5\left(\mathrm{q},{ }^{1} J_{\mathrm{CF}}=272.6, \mathrm{CF}_{3}\right), 133.8\left(\mathrm{~d},{ }^{4} J_{\mathrm{CP}}=2.4\right.$, $\left.p-\mathrm{C}_{\mathrm{Ph}}\right), 131.1\left(\mathrm{~d},{ }^{2} J_{\mathrm{CP}}=9.9, o-\mathrm{C}_{\mathrm{Ph}}\right), 129.3\left(\mathrm{~d},{ }^{3} J_{\mathrm{CP}}=11.6, m-\mathrm{C}_{\mathrm{Ph}}\right)$, $124.9\left(\mathrm{~d},{ }^{1} J=87.5, \mathrm{i}-\mathrm{C}_{\mathrm{Ph}}\right), 89.3\left(\mathrm{~s}, C_{6} \mathrm{Me}_{6}\right), 33.2$ (s, NMe), 16.4 (s, $\left.\mathrm{C}_{6} \mathrm{Me}_{6}\right)$. UV-vis $\left(\mathrm{CH}_{2} \mathrm{Cl}_{2} ; \lambda_{\max }, \mathrm{nm} ; \varepsilon, \mathrm{M}^{-1} \mathrm{~cm}^{-1}\right): 550$ (1300).

\section{Typical procedure for the ROMP of norbornene}

A $50 \mathrm{~mL}$ round-bottom flask equipped with a magnetic stirring bar and capped with a three-way stopcock was charged with the ruthenium complexes $\mathbf{3 - 4}(0.03 \mathrm{mmol})$ and degassed chlorobenzene $(20 \mathrm{~mL})$ was added under an argon atmosphere. The solution was stirred for a few minutes at room temperature and then in an oil bath thermostated at $60{ }^{\circ} \mathrm{C}$. Norbornene (1.5 M in chlorobenzene, $5 \mathrm{~mL}, 7.5 \mathrm{mmol}$ ) and eventually trimethylsilyldiazomethane, TMSD $(0.1 \mathrm{M}$ in a hexanes-chlorobenzene mixture, $1 \mathrm{~mL}, 0.1 \mathrm{mmol}$ ) were added with a syringe, and the reaction mixture was stirred for $2 \mathrm{~h}$ at $60{ }^{\circ} \mathrm{C}$. The conversion was monitored by gas chromatography using norbornane as an internal standard. The resulting gel was diluted with $\mathrm{CHCl}_{3}(20 \mathrm{~mL})$ and slowly poured into $\mathrm{MeOH}$ (500 $\mathrm{mL})$ under vigorous stirring. The precipitated polymer was filtered, dried under dynamic vacuum, and characterized 
Table 3 Crystal data and structure refinement parameters for $3 a-c$ and $4 a-c$

\begin{tabular}{|c|c|c|c|c|c|c|}
\hline & $3 a$ & $3 \mathbf{b}$ & $3 c$ & $4 a$ & $4 b$ & $4 c$ \\
\hline Formula & $\mathrm{C}_{38} \mathrm{H}_{42} \mathrm{ClN}_{2} \mathrm{PRu}$ & $\mathrm{C}_{30} \mathrm{H}_{42} \mathrm{ClN}_{2} \mathrm{PRu}$ & $\mathrm{C}_{26} \mathrm{H}_{34} \mathrm{ClN}_{2} \mathrm{PRu}$ & $\mathrm{C}_{38} \mathrm{H}_{42} \mathrm{~F}_{6} \mathrm{~N}_{2} \mathrm{P}_{2} \mathrm{Ru}$ & $\mathrm{C}_{30} \mathrm{H}_{42} \mathrm{BF}_{4} \mathrm{~N}_{2} \mathrm{PRu}$ & $\mathrm{C}_{58} \mathrm{H}_{46} \mathrm{BF}_{24} \mathrm{~N}_{2} \mathrm{PRu}$ \\
\hline Formula weight & 694.22 & 598.14 & 542.04 & 803.74 & 649.50 & 1369.82 \\
\hline$T, \mathrm{~K}$ & 100 & 100 & 100 & 100 & 100 & 120 \\
\hline Crystal system & Monoclinic & Monoclinic & Triclinic & Monoclinic & Monoclinic & Monoclinic \\
\hline Space group & $P 2_{1} / n$ & $P 2_{1} / c$ & $P \overline{1}$ & $P 2_{1} / n$ & $C 2 / c$ & $P 2_{1} / c$ \\
\hline$Z / Z^{\prime}$ & $4 / 1$ & $4 / 1$ & $2 / 1$ & $4 / 1$ & $8 / 1$ & $4 / 1$ \\
\hline$a, \AA$ & $8.6451(9)$ & $9.890(3)$ & $8.8288(13)$ & $9.7804(6)$ & $25.9645(3)$ & $12.2605(8)$ \\
\hline$b, \AA$ & $20.932(2)$ & $36.718(9)$ & $8.8550(13)$ & $32.185(2)$ & $9.96760(10)$ & $28.9349(15)$ \\
\hline$c, \AA$ & $17.7244(19)$ & $8.509(2)$ & $16.886(3)$ & $12.0350(8)$ & $23.1951(3)$ & $17.1266(10)$ \\
\hline$\alpha, \circ$ & & & $87.525(3)$ & & & \\
\hline$\beta, \circ$ & $99.594(2)$ & $113.639(7)$ & $79.413(2)$ & $107.2960(10)$ & $96.5526(6)$ & $108.197(2)$ \\
\hline$\gamma, \circ$ & & & $68.626(2)$ & & & \\
\hline$V, \AA^{3}$ & $3162.6(6)$ & $2830.4(13)$ & $1208.0(3)$ & $3617.1(4)$ & $5963.76(12)$ & $5771.9(6)$ \\
\hline$d_{\text {calc. }}, \mathrm{g} \mathrm{cm}^{-3}$ & 1.458 & 1.404 & 1.490 & 1.476 & 1.447 & 1.576 \\
\hline$\mu, \mathrm{cm}^{-1}$ & 6.62 & 7.26 & 8.42 & 5.83 & 6.27 & 4.18 \\
\hline $2 \theta_{\max }, \circ$ & 54 & 60 & 54 & 60 & 60 & 56 \\
\hline Refls. collected/independent & 32 206/6902 & $26013 / 8183$ & $16106 / 5286$ & $46296 / 10527$ & $74134 / 8695$ & $41189 / 13856$ \\
\hline Observed reflections $[I>2 \sigma(I)]$ & 4730 & 6453 & 4315 & 7940 & 8146 & 7865 \\
\hline$R_{1}$ & 0.0388 & 0.0385 & 0.0506 & 0.0461 & 0.0218 & 0.0653 \\
\hline $\mathrm{w} R_{2}$ & 0.0670 & 0.0835 & 0.1262 & 0.1043 & 0.0641 & 0.1570 \\
\hline GOF & 1.007 & 1.040 & 1.036 & 1.087 & 1.043 & 1.060 \\
\hline $\begin{array}{l}\text { Residual density, } \\
\mathrm{e} \AA^{-3}\left(d_{\max } / d_{\min }\right)\end{array}$ & $0.798 /-0.735$ & $0.761 /-0.664$ & $2.120 /-0.945$ & $1.526 /-0.927$ & $0.568 /-0.509$ & $1.277 /-0.863$ \\
\hline
\end{tabular}

by NMR spectroscopy and GPC in THF using a polystyrene calibration.

\section{X-ray crystal structure determination}

Single crystals of $\mathbf{3}$ and $\mathbf{4}$ were obtained by slow diffusion of $\mathrm{Et}_{2} \mathrm{O}$ to a solution of a complex $(3 \mathrm{a}, 4 \mathrm{a}-\mathbf{c})$ in $\mathrm{CH}_{2} \mathrm{Cl}_{2}$, or by diffusion of hexane to a solution of $\mathbf{3 b}$ and $\mathbf{3} \mathbf{c}$ in benzene. Data collection for all samples was performed on a Bruker SMART APEX II diffractometer (MoK $\alpha$ radiation, $\lambda=0.71073 \AA$ ) equipped with an Apex II CCD detector. Frames were integrated using the Bruker SAINT software package ${ }^{61}$ by a narrowframe algorithm. A semiempirical absorption correction was applied with the SADABS ${ }^{62}$ program using the intensity data of equivalent reflections. The structures were solved with direct methods and refined by the full-matrix least-squares technique against $F_{h k l}^{2}$ in anisotropic approximation with the SHELX ${ }^{63}$ software package. The positions of hydrogen atoms were calculated, and all hydrogen atoms were refined in a riding model with $1.5 U_{\text {eq }}\left(\mathrm{C}_{\mathrm{m}}\right)$ and $1.2 U_{\text {eq }}\left(\mathrm{C}_{\mathrm{i}}\right)$, where $U_{\text {eq }}\left(\mathrm{C}_{\mathrm{m}}\right)$ and $1.2 U_{\text {eq }}\left(\mathrm{C}_{\mathrm{i}}\right)$ are respectively the equivalent thermal parameters of the methyl and all other carbon atoms to which the corresponding $\mathrm{H}$ atoms are bonded. Detailed crystallographic information is given in Table 3. Crystallographic data have been deposited to the Cambridge Crystallographic Data Centre, CCDC numbers 1475876-1475879, 1494098 and 1494099.

\section{Conclusions}

A series of new $18 \overline{\mathrm{e}}$ and $16 \overline{\mathrm{e}}$ hexamethylbenzene ruthenium complexes with the iminophosphonamide ligand have been synthesized and fully characterized. The elongated $\mathrm{Ru}-\mathrm{Cl}$ bonds and an easy dissociation of the chloride anion in the
$18 \bar{e}$ complexes $3 \mathbf{a}-\mathbf{c}$ as well as short $\mathrm{Ru}-\mathrm{N}$ bonds in the $16 \overline{\mathrm{e}}$ complexes $\mathbf{4 a - c}$ and small puckering of the $\mathrm{Ru}-\mathrm{N}-\mathrm{P}-\mathrm{N}$ metallacycle indeed suggest the zwitterionic nature and strong $\sigma, \pi$-donor character of the iminophosphonamide ligand being able to donate $4 \overline{\mathrm{e}}$ or $6 \overline{\mathrm{e}}$. Due to charge separation between the phosphorus and the nitrogen atoms, the electronic properties of the NPN-ligand are similar to those of dianionic ligands and therefore it can efficiently stabilize $16 \bar{e}$ electron deficient complexes. Among other arene ruthenium complexes with $\kappa^{2}-N, N$ chelating ligands, the properties of $16 \overline{\mathrm{e}}$ iminophosphonamide complexes resemble those of strongly donating monoanionic $\beta$-diketiminates and dianionic bis (imidazolin-2-iminates), and render them air stable unlike the analogous air-sensitive $16 \overline{\mathrm{e}}$ amidinate complexes. Thus arene ruthenium complexes $\mathbf{3} \mathbf{a}, \mathbf{b}$ and $\mathbf{4 a}, \mathbf{b}$ bearing the strongly donating NPN-ligand perform better than the analogous ruthenium amidinates in the ROMP of strained norbornene. To properly address the unusually low activity of complexes $3 \mathbf{c}, \mathbf{4 c}$ with the most electron-rich NPN-ligand, which seems to block the activation of the ruthenium center by carbene, a deeper mechanistic investigation is required. The detailed kinetic and thermodynamic studies on the dissociation of the chlorides $3 \mathbf{a}-\mathbf{c}$ and the coordination of various ligands to their $16 \overline{\mathrm{e}}$ counterparts $\mathbf{4 a - c}$ as well as the ROMP mechanistic study and application in the transfer hydrogenation of ketones are in progress and to be reported soon.

\section{Acknowledgements}

The authors thank the Russian Foundation for Basic Research (grant no. 14-03-00345) for financial support. 


\section{Notes and references}

1 R. Vollmerhaus, R. Tomaszewski, P. Shao, N. J. Taylor, K. J. Wiacek, S. P. Lewis, A. Al-Humydi and S. Collins, Organometallics, 2005, 24, 494-507.

2 R. Vollmerhaus, P. Shao, N. J. Taylor and S. Collins, Organometallics, 1999, 18, 2731-2733.

3 M. Witt, M. Noltemeyer, H.-G. Schmidt, T. Lübben and H. W. Roesky, J. Organomet. Chem., 1999, 591, 138-147.

4 E. Müller, J. Müller, F. Olbrich, W. Brüser, W. Knapp, D. Abeln and F. T. Edelmann, Eur. J. Inorg. Chem., 1998, 1998, 87-91.

5 C. Qi and S. Zhang, Appl. Organomet. Chem., 2006, 20, 7073.

6 R. Tomaszewski, R. Vollmerhaus, A. Al-Humydi, Q. Wang, N. J. Taylor and S. Collins, Can. J. Chem., 2006, 84, 214-224.

7 K. Albahily, V. Fomitcheva, S. Gambarotta, I. Korobkov, M. Murugesu and S. I. Gorelsky, J. Am. Chem. Soc., 2011, 133, 6380-6387.

8 K. Albahily, V. Fomitcheva, Y. Shaikh, E. Sebastiao, S. I. Gorelsky, S. Gambarotta, I. Korobkov and R. Duchateau, Organometallics, 2011, 30, 4201-4210.

9 K. Albahily, S. Licciulli, S. Gambarotta, I. Korobkov, R. Chevalier, K. Schuhen and R. Duchateau, Organometallics, 2011, 30, 3346-3352.

10 K. Albahily, Y. Shaikh, E. Sebastiao, S. Gambarotta, I. Korobkov and S. I. Gorelsky, J. Am. Chem. Soc., 2011, 133, 6388-6395.

11 R. Boese, M. Düppmann, W. Kuchen and W. Peters, Z. Anorg. Allg. Chem., 1998, 624, 837-845.

12 R. Schubbe, K. Angermund, G. Fink and R. Goddard, Macromol. Chem. Phys., 1995, 196, 467-478.

13 W.-J. Guo and Z.-X. Wang, J. Org. Chem., 2013, 78, 10541061.

14 B. Prashanth and S. Singh, J. Chem. Sci., 2015, 127, 315-325.

15 R. L. Stapleton, J. Chai, N. J. Taylor and S. Collins, Organometallics, 2006, 25, 2514-2524.

16 I. V. Shishkov, F. Rominger and P. Hofmann, Organometallics, 2009, 28, 1049-1059.

17 B. F. Straub, F. Eisentrager and P. Hofmann, Chem. Commun., 1999, 2507-2508.

18 P. Hofmann, I. V. Shishkov and F. Rominger, Inorg. Chem., 2008, 47, 11755-11762.

19 B. F. Straub, F. Rominger and P. Hofmann, Organometallics, 2000, 19, 4305-4309.

20 B. F. Straub, F. Rominger and P. Hofmann, Chem. Commun., 2000, 1611-1612.

21 B. F. Straub, I. Gruber, F. Rominger and P. Hofmann, J. Organomet. Chem., 2003, 684, 124-143.

22 N. Nebra, C. Lescot, P. Dauban, S. Mallet-Ladeira, B. Martin-Vaca and D. Bourissou, Eur. J. Org. Chem., 2013, 984-990.

23 B. F. Straub and P. Hofmann, Angew. Chem., Int. Ed., 2001, 40, 1288-1290.

24 W. Keim, R. Appel, A. Storeck, C. Krüger and R. Goddard, Angew. Chem., Int. Ed., 1981, 20, 116-117.
25 S. Collins, Coord. Chem. Rev., 2011, 255, 118-138.

26 P. J. Bailey, K. J. Grant and S. Parsons, Organometallics, 1998, 17, 551-555.

27 T. A. Peganova, A. V. Valyaeva, A. M. Kalsin, P. V. Petrovskii, A. O. Borissova, K. A. Lyssenko and N. A. Ustynyuk, Organometallics, 2009, 28, 3021-3028.

28 More correctly, Chart 1 shows the symmetry adapted linear combinations (SALC) of the atomic orbitals. The corresponding molecular orbitals retain the same symmetry elements, however their designation transforms either to $\mathrm{A}_{2}$ and $\mathrm{B}_{1}$ or $\mathrm{A}^{\prime \prime}$ and $\mathrm{A}^{\prime}$, respectively for the planar or lateral coordination of the metal atom. Here we used the point group symmetries for SALC to be independent of the symmetry of the resulting complex.

29 H. Kondo, T. Sue, A. Kageyama, Y. Yamaguchi, Y. Sunada and H. Nagashima, J. Organomet. Chem., 2009, 694, 795-800.

30 T. Hayashida, Y. Yamaguchi, K. Kirchner and H. Nagashima, Chem. Lett., 2001, 954-955.

31 Y. Yamaguchi and H. Nagashima, Organometallics, 2000, 19, 725-727.

32 H. Nagashima, H. Kondo, T. Hayashida, Y. Yamaguchi, M. Gondo, S. Masuda, K. Miyazaki, K. Matsubara and K. Kirchner, Coord. Chem. Rev., 2003, 245, 177-190.

33 H. Kondo, Y. Yamaguchi and H. Nagashima, J. Am. Chem. Soc., 2001, 123, 500-501.

34 C. Bibal, M. Pink, Y. D. Smurnyy, J. Tomaszewski and K. G. Caulton, J. Am. Chem. Soc., 2004, 126, 2312-2313.

35 C. Bibal, Y. D. Smurnyy, M. Pink and K. G. Caulton, J. Am. Chem. Soc., 2005, 127, 8944-8945.

36 O. V. Gusev, T. A. Peganova, A. V. Gonchar, P. V. Petrovskii, K. A. Lyssenko and N. A. Ustynyuk, Phosphorus, Sulfur Silicon Relat. Elem., 2009, 184, 322-331.

37 O. J. Scherer and P. Klusmann, Z. Anorg. Allg. Chem., 1969, 370, 171.

38 M. Düppmann, W. Kuchen, W. Peters and W. Phosphorus, Sulfur Silicon Relat. Elem., 1997, 129, 53-58.

39 A. D. Phillips, G. Laurenczy, R. Scopelliti and P. J. Dyson, Organometallics, 2007, 26, 1120-1122.

40 T. Singh, R. Kishan, M. Nethaji and N. Thirupathi, Inorg. Chem., 2012, 51, 157-169.

41 T. Hayashida and H. Nagashima, Organometallics, 2002, 21, 3884-3888.

42 P. J. Bailey, L. A. Mitchell and S. Parsons, J. Chem. Soc., Dalton Trans., 1996, 2839-2841.

43 W. W. Seidel, W. Dachtler and T. Pape, Z. Anorg. Allg. Chem., 2012, 638, 116-121.

44 I. J. Munslow, A. R. Wade, R. J. Deeth and P. Scott, Chem. Commun., 2004, 2596-2597.

45 C. F. Barboza da Silva, S. Schwarz, M. Galceran Mestres, S. Teijelo López and J. Strähle, Z. Anorg. Allg. Chem., 2004, 630, 1919-1923.

46 A. D. Phillips, O. Zava, R. Scopelitti, A. A. Nazarov and P. J. Dyson, Organometallics, 2010, 29, 417-427.

47 A. D. Phillips, K. Thommes, R. Scopelliti, C. Gandolfi, M. Albrecht, K. Severin, D. F. Schreiber and P. J. Dyson, Organometallics, 2011, 30, 6119-6132. 
48 T. Glöge, D. Petrovic, C. Hrib, P. G. Jones and M. Tamm, Eur. J. Inorg. Chem., 2009, 4538-4546.

49 A. Bondi, J. Phys. Chem., 1964, 68, 441-451.

50 R. S. Rowland and R. Taylor, J. Phys. Chem., 1996, 100, 7384-7391.

51 T. Hayashida, H. Kondo, J. I. Terasawa, K. Kirchner, Y. Sunada and H. Nagashima, J. Organomet. Chem., 2007, 692, 382-394.

52 A. D. Bain, Prog. Nucl. Magn. Reson. Spectrosc., 2003, 43, 63103.

53 Although we observe the formation of the cationic $16 \overline{\mathrm{e}}$ species in the solution of $\mathbf{3 c}$ in chloroform or dichloromethane proving them to be possible intermediates, the actual exchange mechanism in apolar solvents can be more complicated or even different from the one given in the simplified Scheme 2.

54 K. Mashima, H. Kaneyoshi, S. Kaneko, A. Mikami, K. Tani and A. Nakamura, Organometallics, 1997, 16, 10161025.

55 A. W. Stumpf, E. Saive, A. Demonceau and A. F. Noels, J. Chem. Soc., Chem. Commun., 1995, 1127-1128.
56 A. Demonceau, A. W. Stumpf, E. Saive and A. F. Noels, Macromolecules, 1997, 30, 3127-3136.

57 T. Hayashida and H. Nagashima, Organometallics, 2001, 20, 4996-4998.

58 The model reaction of $\mathbf{4 b}$ with 3 equiv. of TMSD in dichloromethane resulted in a complex mixture of products, one of each having the signal in ${ }^{31} \mathrm{P}$ NMR at $\delta 78.3$ perhaps corresponds to a carbene complex (a characteristic doublet in ${ }^{1} \mathrm{H}$ NMR at $\delta 9.2$ with $J_{\mathrm{H}-\mathrm{P}}=16 \mathrm{~Hz}$ ). To define the structures of all the species formed and their evolution with time in the ROMP catalytic cycle further mechanistic investigation is to be carried out.

59 M. Bennett, T. N. Huang, T. Matheson, A. Smith, S. Ittel and W. Nickerson, Inorg. Synth., 1982, 21, 74-78.

60 N. A. Yakelis and R. G. Bergman, Organometallics, 2005, 24, 3579-3581.

61 Bruker, SAINT v7.23A, 2005.

62 G. M. Sheldrick, SADABS v2008/1, Bruker/Siemens Area Detector Absorption Correction Program, 2008.

63 G. M. Sheldrick, Acta Crystallogr., Sect. C: Cryst. Struct. Commun., 2015, 71, 3-8. 